\title{
PRIMARY CAUSES OF WETLAND LOSS AT MADISON BAY, TERREBONNE PARISH, LOUISIANA
}

Robert A. Morton, Ginger Tiling, and Nicholas F. Ferina

\author{
U.S. Geological Survey \\ Center for Coastal and Watershed Studies \\ St. Petersburg, FL 33701
}

Open File Report 03-60 



\section{TABLE OF CONTENTS}

INTRODUCTION _. 


\section{SUMMARY}

Water depths, marsh surface elevations, and correlative stratigraphic markers in 10 sediment cores from Madison Bay in Terrebonne Parish, Louisiana provide a basis for estimating the magnitudes and rates of marsh erosion and land subsidence at one of the best known wetland loss hotspots in coastal Louisiana. Results of this field study show that water about $1 \mathrm{~m}$ deep now covers former marshes in Madison Bay. About two thirds of the permanent flooding was caused by rapid subsidence that occurred in the late 1960s, whereas the other third was caused by subsequent erosion of the delta plain marsh. Subsidence rates near Madison Bay estimated independently by other investigators from buried peats, recent marsh surface measurements, and tide gauge records clearly show that subsidence rates since the 1960s ( $23 \mathrm{~mm} / \mathrm{yr})$ are an order of magnitude greater than geological subsidence rates averaged for the past 400 to $4000 \mathrm{yrs}(\sim 2$ $\mathrm{mm} / \mathrm{yr})$.

Wetland losses in the Mississippi delta plain accelerated rapidly in the 1960s, peaked in the 1970s, and then began to decline. Physical and biogeochemical processes identified previously as major contributors to wetland loss cannot easily explain these historical patterns. There are, however, close temporal and spatial correlations among regional wetland loss, high subsidence rates, and large-volume fluid production from nearby oil and gas fields. The recent decreased rates of wetland loss may be related to decreased rates of subsidence caused by significantly decreased rates of subsurface fluid withdrawal.

Annual production of gas, oil, and formation water from the Lapeyrouse, Lirette, and Bay Baptiste fields that encompass the Madison Bay hotspot accelerated in the 1960s, peaked about 1970, and then began a rapid decline. Large decreases in pore pressure in gas reservoirs of the Lapeyrouse field have likely altered the subsurface state of stress and reactivated a major fault. The displacement, orientation, and projected surficial intersection of the fault coincide with the Madison Bay wetland loss hotspot. Therefore wetland losses at Madison Bay can be closely linked to rapid subsidence and possible fault reactivation induced by long-term, large-volume hydrocarbon production.

\section{INTRODUCTION}

Wetland losses in the lower Mississippi delta have been the subject of intensive investigations ever since the magnitude of the wetland loss problem and its potential economic and social impacts were first recognized (Gosselink and Baumann, 1980; Gagliano et al., 1981). Literally

hundreds of reports have been written about the complex physical and biogeochemical processes and their interdependencies that are responsible for wetland loss (Turner and Cahoon, 1987; Boesch et al., 1994; Roberts et al., 1994; Williams et al., 1994; Day et al., 2000; Penland et al., 2000). Despite the multitude of prior studies, there still are controversies and unanswered questions regarding the primary importance of natural versus induced environmental changes that have caused the most recent dramatic losses in wetlands. Most of the prior studies of wetland 
loss in Louisiana focused on surficial hydrodynamic processes and wetlands ecology and did not consider any subsurface processes (Craig et al., 1979; Mendelssohn and McKee, 1988; Day et al., 1994; Nyman et al., 1994; Turner, 1997). The few studies that considered possible subsurface controls on wetland loss concentrated on the most recent (Holocene) alluvial and deltaic deposits (Kuecher et al., 1993; Suhayda et al., 1993; Roberts et al., 1994) and did not consider the deeper late Quaternary and Tertiary strata. The only studies or reviews that actually examined the deep basin fill and possible surficial changes induced by hydrocarbon production concluded that the impacts of production induced subsidence are insignificant, or are more local than regional (Coleman and Roberts, 1989; Boesch et al., 1994). A study in Louisiana designed specifically to evaluate potential wetland subsidence induced by hydrocarbon production concluded that it is minimal (Suhayda, 1987). Also, the official website of the Department of Natural Resources in Louisiana states that production induced subsidence in coastal Louisiana is negligible http: /www.dnr.state.la.us/).

Wetlands in southcentral Louisiana have been converted to open water within the interior of the subaerial marsh and around the shores of water bodies. The pre-existing water bodies (bays, lakes, and ponds) are natural components of the delta plain (Fig. 1). Wetland losses around the margins of delta-plain water bodies result either from erosion by waves or inundation by a relative rise in sea level (submergence). In some ponds, strong winds are capable of generating enough wave energy that marsh erosion is common, and subsequent enlargement of delta plain water bodies can result in both expanded surface areas and increased water depths (Day et al., 1994).

Wetland loss hotspots, which are areas of interior wetlands of the Mississippi delta plain that deteriorate rapidly for no apparent reason, have perplexed wetland ecologists for decades. Hotspots typically originate where the rates of loss are high and the conversion of wetlands to open water follows a specific temporal sequence and spatial pattern. The hotspots normally begin as isolated patches or ponds of open water that are surrounded by dense stands of continuous healthy marsh vegetation (Leibowitz and Hill, 1987). As the marsh deteriorates, the ponds gradually enlarge, merge, and the wetland loss hotspot becomes mostly open water with a few remnant islands of marsh. Eventually the scattered islands of marsh disappear, and all the former continuous marsh is replaced by open water.

There are two possible explanations for the greatest and most rapid interior wetland losses in southcentral Louisiana. One possibility is that erosion of the organic-rich marsh sediments is primarily responsible for the changes from interior wetlands to open water. According to this explanation the marsh plants are weakened and die either as a result of water logging or salt-water intrusion (Gosselink et al., 1977; Mendelssohn and McKee, 1988). When plant density decreases, the hydrodynamic forces present in the marsh begin to erode and remove the organic-rich sediments from the marsh. Once the organic sediments are in suspension, they can be exported from the deteriorating marsh into adjacent water bodies or other marshes by currents driven by tidal and meteorological processes. Another possibility is that the observed historical changes from interior wetlands to open water are primarily caused by land-surface subsidence (Bosch et al., 

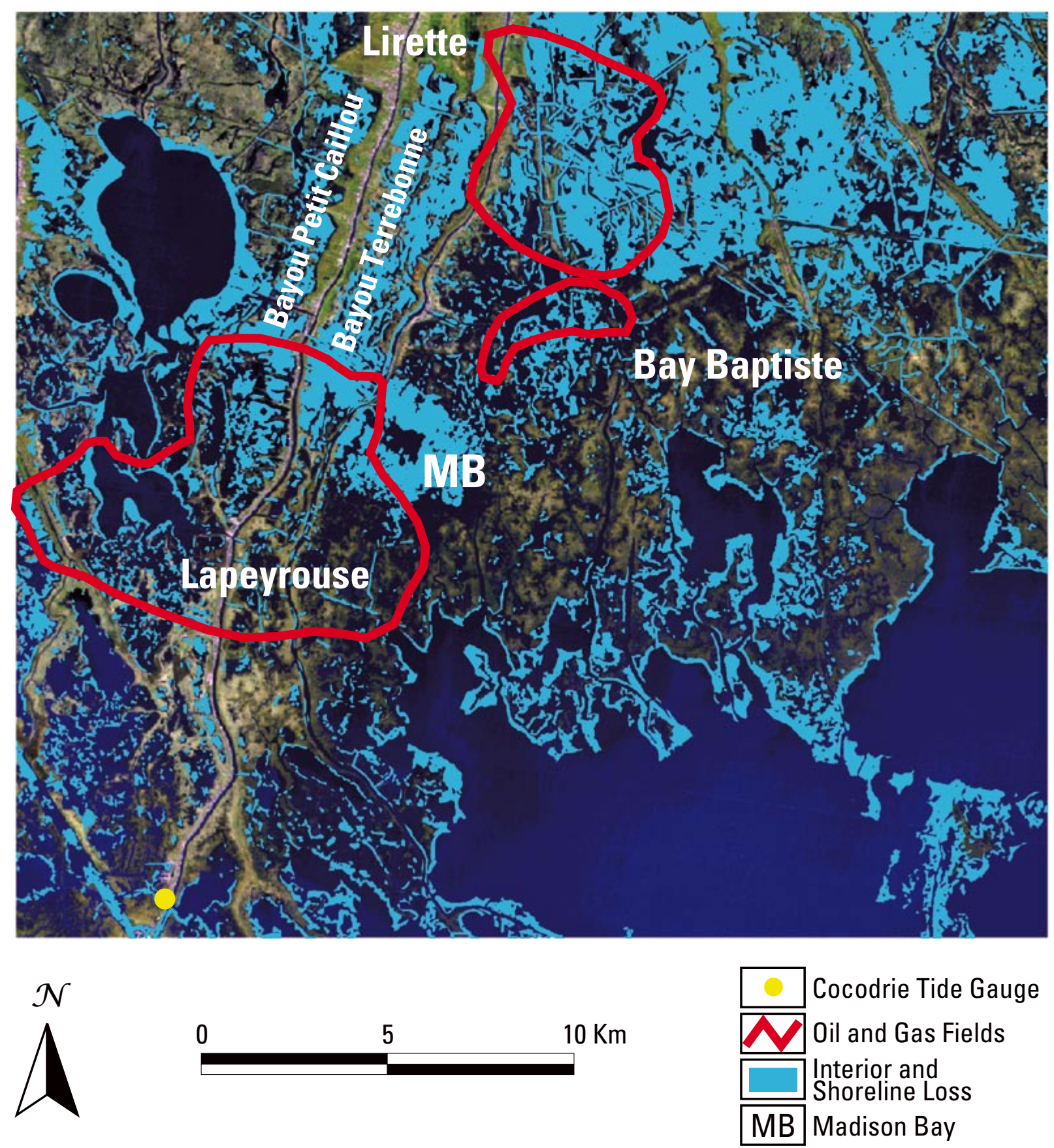

Figure 1. Regional map of southcentral Louisiana showing location of Madison Bay, the Cocodrie tide gauge, and the distribution of wetland losses relative to producing oil and gas fields and potentially active faults.

1994). If that explanation is correct, then some of the roots and organic-rich marsh sediments may be preserved under water at the site that subsided. Neither of these two explanations is mutually exclusive and both land subsidence and sediment erosion may partly contribute to the wetland changes that have been observed.

Rapid interior wetland losses of the Mississippi delta have been the most difficult to explain because initially the hotspots do not involve erosion. Because hotspots account for approximately $43 \%$ of the marsh loss in south Louisiana (Leibowitz and Hill, 1987), understanding the 
processes causing those losses would help explain much of the total wetland losses. The purpose of this study is to examine the physical processes responsible for rapid interior wetland losses at Madison Bay, a typical delta-plain wetland loss hotspot in Terrebonne Parish Louisiana (Fig.1). This site was selected for detailed investigation to examine processes at a hotspot where (1) prior investigations were unable to explain the rapid wetland losses (DeLaune et al., 1994; Reed, 1995), (2) erosion was not the mechanism that initiated wetland loss, and (3) contemporaneous data were available for wetland losses, subsidence rates, and hydrocarbon production.

\section{Madison Bay Hot Spot}

The Madison Bay hot spot (Figs. 2 and 3) is located in delta plain marshes that are associated with the Lafourche subdelta complex of the Mississippi delta. This delta lobe was deposited by the Bayou Terrebonne distributary system, including the Bayou Grand Calliou and Bayou Petit Calliou distributary channels, which were active from about $1200 \mathrm{yrs}$ BP to about $400 \mathrm{yrs}$ BP (Frazier, 1967).

The history of recent marsh loss at Madison Bay was chronicled for 7 consecutive periods between 1941 and 1990 (Reed, 1995). The marshes were classified as brackish in the 1940s and 1950s but were saline marshes by the 1970s (DeLaune et al., 1994). Wetland losses were minor from the early 1940s to the late 1960s suggesting equilibrium conditions between delta plain processes and marsh vitality even though the salinity was increasing. However, between 1969 and 1978 wetlands deteriorated rapidly, suggesting a change in local conditions and delta plain processes. Wetland ecologists have been perplexed by the rapid deterioration of marshes at Madison Bay (Nyman et al., 1993, DeLaune et al. 1994, Cahoon et al., 1999, Reed, 1995) because only a few dredged canals crossed the disintegrating marsh (Reed, 1995) and there was no other evidence of human activities that would cause direct wetland losses. All of these studies of marsh loss at Madison Bay recognized that despite exceptionally high rates of marsh aggradation $(9.8 \mathrm{~mm} / \mathrm{yr})$, the local supply of mineral matter and plant production were unable to overcome

high rates of submergence (Nyman et al., 1993). None of these studies addressed the mechanisms of regional submergence (subsidence) although DeLaune et al. (1994) speculated that marsh elevation loss at Madison Bay was related to peat collapse.

\section{Field Methods}

The field activities in Madison Bay on April 30 and May 1, 2002 involved collecting vibracores, measuring water depths, and monitoring water levels (Table 1). Ten short vibracores were collected within and around the Madison Bay wetland loss hotspot (Figs. 2 and 3, and Appendix A). The cores were located with a portable GPS receiver. Core sites were selected to encompass the perimeter of the area that experienced the most rapid wetland loss and to provide close correlations between pairs of cores taken in the interior marsh and adjacent open water (Figs. 2 and 3). Together the coring sites were intended to evaluate the physical processes 


\begin{tabular}{|c|l|l|l|l|l|l|}
\hline Day & $\begin{array}{c}\text { Local } \\
\text { Time }\end{array}$ & Event & $\begin{array}{c}\text { Measured } \\
\text { Water Depth } \\
(\mathrm{cm})\end{array}$ & $\begin{array}{c}\text { Cocodrie } \\
\text { Gauge } \\
(\mathrm{cm})\end{array}$ & $\begin{array}{c}\text { Staff-gauge } \\
\text { Difference } \\
(\mathrm{cm})\end{array}$ & $\begin{array}{l}\text { Correction } \\
\text { Relative to } \\
\text { Gauge (cm) }\end{array}$ \\
\hline $4 / 30 / 02$ & 1030 & Set staff & 30.5 & 30.5 & 0.00 & 30.5 \\
\hline & 1040 & MB 01 & 82.3 & 30.8 & 0.15 & 31.0 \\
\hline & 1110 & MB 02 & 97.6 & 32.3 & 0.46 & 32.8 \\
\hline & 1130 & MB 03 & 115.9 & 32.3 & 0.91 & 33.2 \\
\hline & 1200 & MB 04 & 149.4 & 33.9 & 1.37 & 35.2 \\
\hline & 1230 & MB 05 & 134.2 & 34.2 & 1.83 & 36.0 \\
\hline & 1252 & Staff read & 36.6 & 34.5 & 2.13 & 36.6 \\
\hline $5 / 01 / 02$ & 1330 & MB 06 & 100.7 & 34.8 & 2.29 & 37.1 \\
\hline & 1000 & Staff read & 27.4 & 28.7 & -1.22 & 27.5 \\
\hline & 1030 & MB 07 & 12.2 & 29.6 & 0.91 & 30.5 \\
\hline & 1100 & MB 08 & 21.4 & 33.5 & 1.83 & 35.4 \\
\hline & 1130 & MB 09 & 27.4 & 35.7 & 2.75 & 38.4 \\
\hline & 1230 & MB 10 & 18.3 & 39 & 3.66 & 42.7 \\
\hline & 1300 & Bathy & Multi & 40.6 & 4.58 & 45.1 \\
\hline & 1315 & Staff read & 45.8 & 40.6 & 5.18 & 45.8 \\
\hline
\end{tabular}

Table 1. Chronology of coring events and water level measurements in Madison Bay were adjusted for the difference between the tide gauge at Cocodrie and the staff gauge in Madison Bay.

that resulted in rapid wetland loss. The cores, which range in length from 3.5 to $4.9 \mathrm{~m}$, were transported to the USGS Center for Coastal and Watershed Studies at St. Petersburg, Florida. Each core was cut into $1 \mathrm{~m}$ sections, each section was split lengthwise, one half of the core was cleaned, photographed, and described in detail, and all the core sections were then placed in containers and stored for future reference. The core descriptions and photographs provided a basis for identifying the predominant sedimentary facies and for selecting stratigraphic contacts and marker horizons that could be correlated between core pairs (Table 2).

Water depths at the open-water coring sites and along the bathymetric profile (Figs. 2 and 3) were measured from a small boat with a graduated rod, while the geographic coordinates of each depth measurement were obtained with a GPS receiver. At the start of the fieldwork a graduated rod was placed at the edge of the eastern marsh (Figs. 2 and 3) and used as a temporary staff gauge to measure the movement of water levels within Madison Bay during the field operations. 

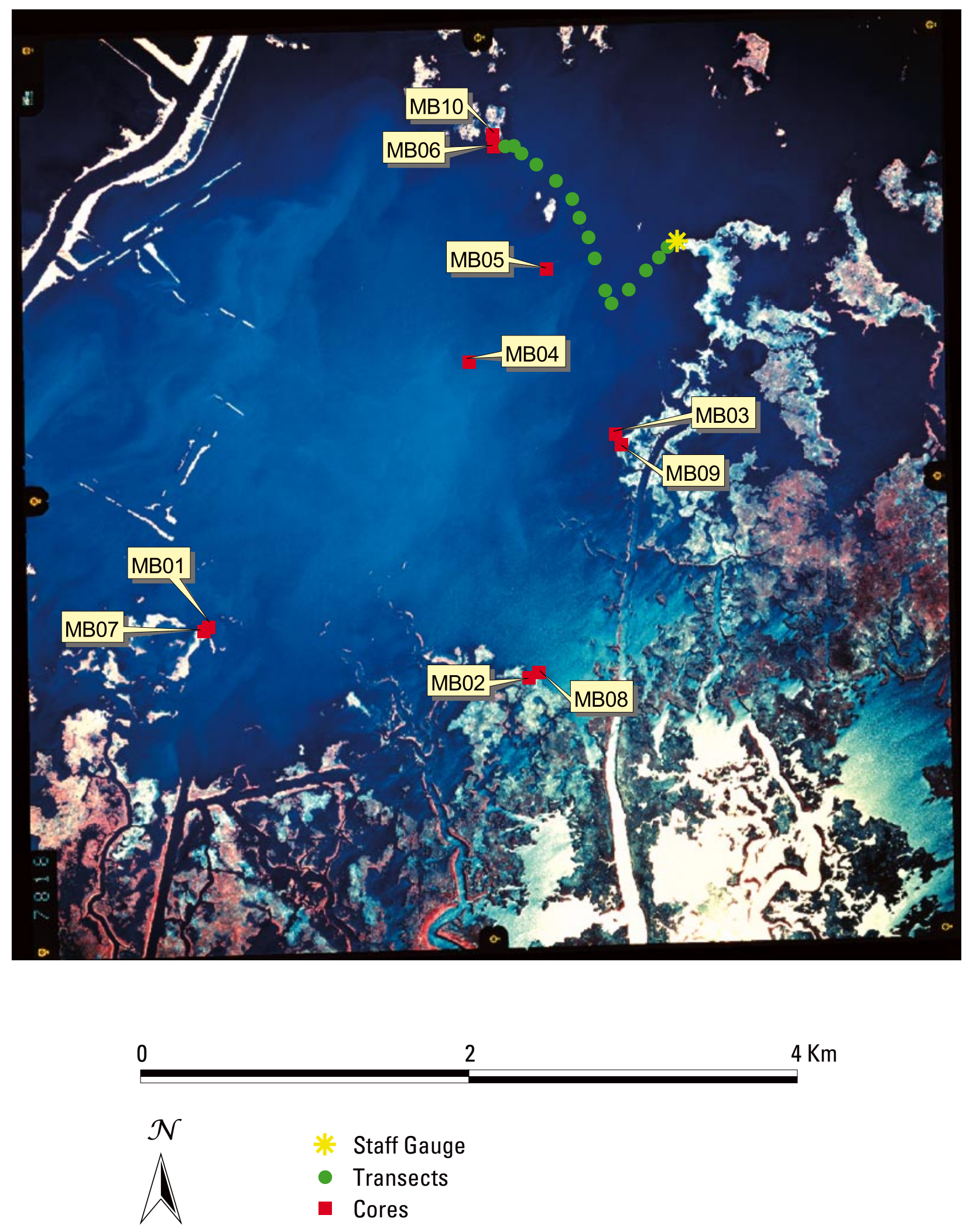

Figure 2. Locations of sediment cores from the Madison Bay area superimposed on an aerial photograph taken in 2000. 

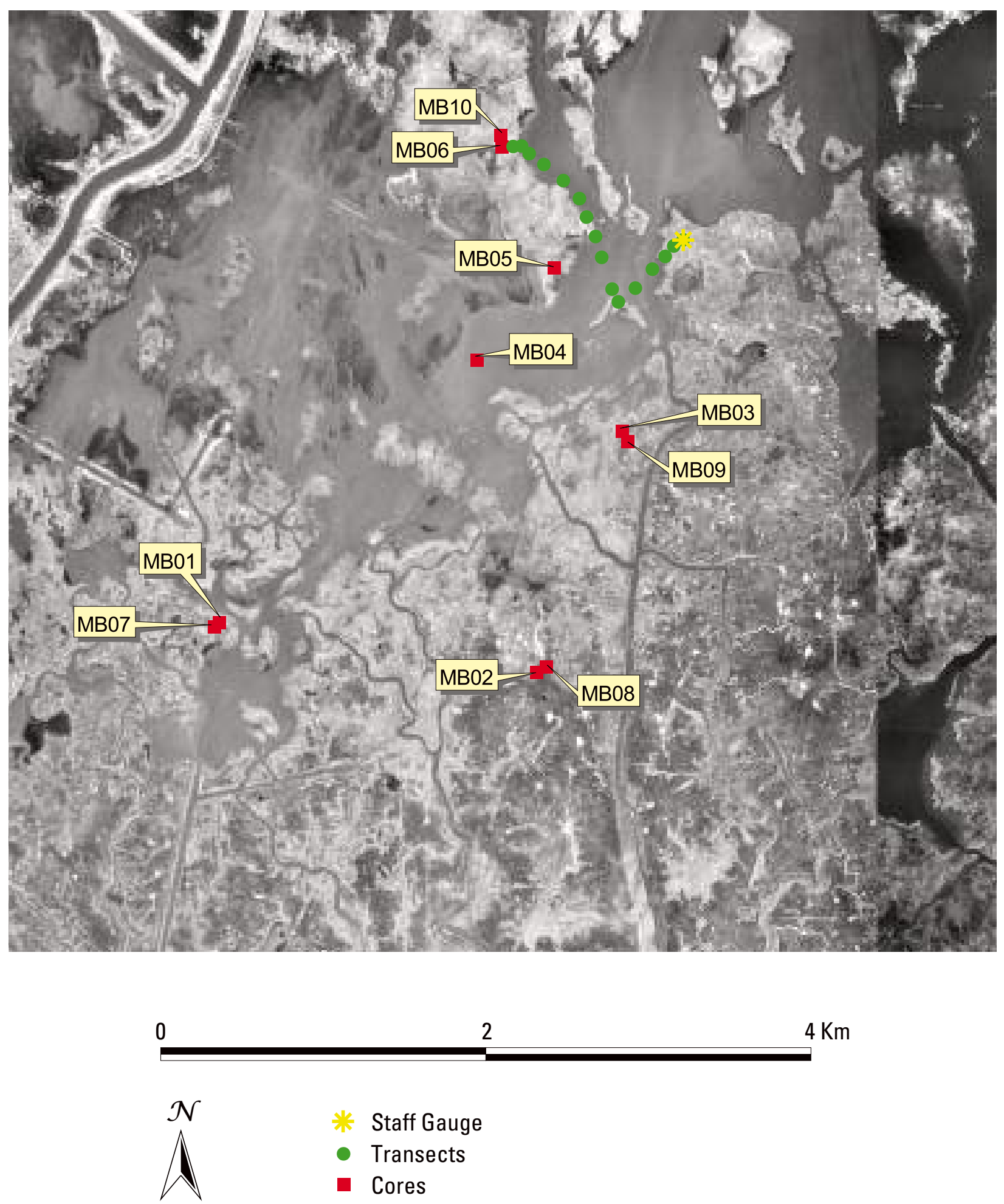

Figure 3. Locations of sediment cores from the Madison Bay area superimposed on an aerial photograph taken in 1990. 


\begin{tabular}{|c|l|l|l|l|l|l|l|}
\hline Contact & MB 01 & MB 07 & Diff. & Contact & MB 02 & MB 08 & Diff. \\
\hline Org/clast & 168 & 176 & 8 & First marsh & 154 & 180 & 26 \\
\hline Org/clast & 186 & 192 & 6 & Org band & 166 & 190 & 24 \\
\hline First marsh & 206 & 208 & 2 & Clast band & 172 & 196 & 24 \\
\hline & & & & Org band & 177 & 202 & 25 \\
\hline Contact & MB 03 & MB 09 & Diff. & Contact & MB 06 & MB 10 & Diff. \\
\hline Last flood & 118 & 146 & 28 & First marsh & 129 & 153 & 24 \\
\hline First marsh & 137 & 168 & 31 & Org/clast & 175 & 198 & 23 \\
\hline Org band & 160 & 192 & 32 & Clast/org & 177 & 202 & 25 \\
\hline & & & & Org band & 184 & 210 & 26 \\
\hline Contact & MB 03 & MB 04 & Diff. & Contact & MB 04 & MB 05 & Diff. \\
\hline Last flood & 118 & 90 & 28 & Last flood & 90 & 111 & 21 \\
\hline First marsh & 137 & 135 & 2 & First marsh & 135 & 134 & -1 \\
\hline
\end{tabular}

Table 2. Core depths, in $\mathrm{cm}$, of stratigraphic markers correlated between core pairs. The most prominent markers are contacts between predominantly organic and predominantly clastic sediments. Org=organic, Clast=clastic, Diff=difference.

The staff gauge was arbitrarily set in the water so that the gauge read $30.5 \mathrm{~cm}$, which fortunately coincided with the same reading at the Cocodrie tide gauge at the same time (Table 1). This coincidence minimized the corrections needed to adjust the water levels in Madison Bay to the National Geodetic Vertical Datum (NGVD) datum of the tide gauge. The staff gauge was read at the beginning and ending of field work each day and those readings were compared to water levels at the Cocodrie tide gauge to provide continuous water level corrections (Fig. 4, Table 1). Despite some setup in Madison Bay from moderately strong onshore wind in the afternoons, water levels were only slightly higher than those at the Cocodrie tide gauge (Table 1).

Water depths measured in the field (Table 1, Fig. 5) can be compared only if they are corrected for tidal stage or any unusual conditions (such as local wind setup) that would bias the data. The New Orleans District U.S. Army Corps of Engineers (USACE) operates a network of tide gauges located throughout the coastal waters of south Louisiana, including the Cocodrie gauge, which is located about $16 \mathrm{~km}$ from the Madison Bay study area (Fig. 1). Using electronic tide gauge data from the USACE website, primary water levels for the dates and times of data collection were plotted (Fig. 4) relative to the NGVD. The digital water-level records provided by the USACE are elevations relative to NGVD, so no additional corrections were necessary for the water level adjustments. The mean higher high water (MHHW) datum closely approximates the flooding surface to which wetlands aggrade when they are in equilibrium with the extant coastal processes. However, information provided online for the Cocodrie tide gauge does not 


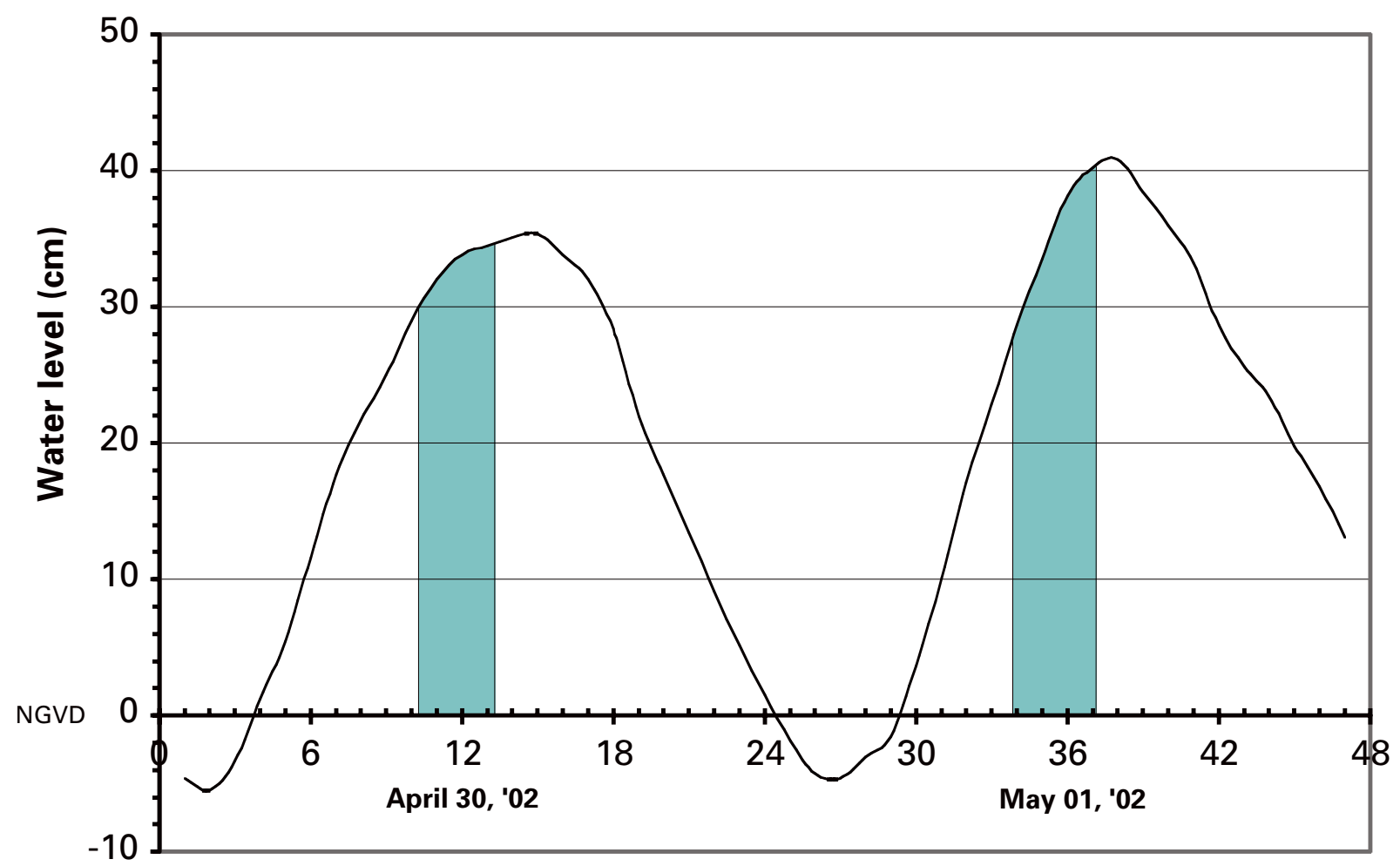

Figure 4. Water levels recorded at the Cocodrie tide gauge on April 30 and May 1, 2002. Phases of the tides during field operations are highlighted (in color). Gauge location is shown in Figure 1.

give the elevation of MHHW, so NGVD was used as the local datum for establishing elevations and water depths in Madison Bay.

Uncorrected water depths measured at the open-water coring sites and along the bathymetric profile ranged from 0.82 to $2.1 \mathrm{~m}$. These measurements were made while water levels were rising toward high tide (Fig. 4), so the values were adjusted downward about 30 to $45 \mathrm{~cm}$ to make

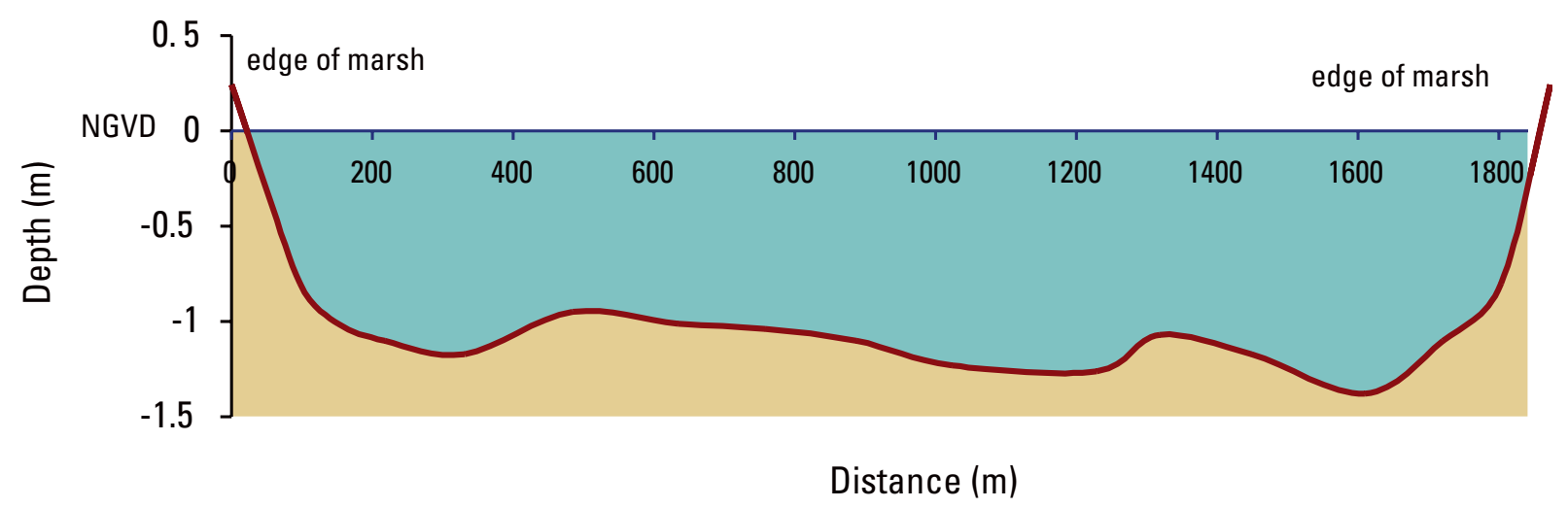

Figure 5. Bathymetric profile in Madison Bay surveyed May 1, 2002 between MB 10 and the staff tide gauge. Location shown in Figures 2 and 3. 


\begin{tabular}{|l|l|l|l|l|}
\hline Core & $\begin{array}{c}\text { Water Depth } \\
(\mathrm{cm})\end{array}$ & $\begin{array}{c}\text { Correction } \\
(\mathrm{cm})\end{array}$ & $\begin{array}{c}\text { NGVD } \\
\text { Elev. }(\mathrm{cm})\end{array}$ & $\begin{array}{c}\text { Shorten } \\
(\mathrm{cm})\end{array}$ \\
\hline MB 01 & 82.3 & 31.0 & -51.3 & 58 \\
\hline MB 02 & 97.6 & 32.8 & -64.8 & 8 \\
\hline MB 03 & 115.9 & 33.2 & -82.7 & 21 \\
\hline MB 04 & 149.4 & 35.2 & -114.2 & 43 \\
\hline MB 05 & 134.2 & 36.0 & -98.2 & 14 \\
\hline MB 06 & 100.7 & 37.1 & -63.6 & 27 \\
\hline MB 07 & 12.2 & 30.5 & 18.3 & 90 \\
\hline MB 08 & 21.4 & 35.4 & 14.0 & 47 \\
\hline MB 09 & 27.4 & 38.4 & 11.0 & 52 \\
\hline MB 10 & 18.3 & 42.7 & 24.4 & 82 \\
\hline
\end{tabular}

Table 3. Measured water depth, water level relative to the Cocodrie tide gauge datum, core elevation adjusted to the Cocodrie tide gauge datum, and amount of core shortening.

them consistent with NGVD (Table 1). These water depths represent significant sediment erosion and/or land subsidence, considering that most of the open-water sites were formerly marsh with elevations above NGVD (Table 3).

\section{SEDIMENT TYPES AND DEPOSITIONAL HISTORY}

\section{Sediment Descriptions}

The vibracores from Madison Bay recovered a succession of unconsolidated sediments representing four sedimentary facies (Fig. 6) that are consistently arranged in the same stratigraphic order at each coring site. From youngest to oldest the common facies are: (1) peat and organicrich mud, (2) massive mud, (3) sand and silty sand, and (4) interbedded sand and mud.

The upper 20 to $30 \mathrm{~cm}$ of modern marsh sediments (cores MB 07, MB 08, MB 09, and MB 10; Appendix A) consist of water-saturated gray or brown mud interspersed among large fibrous roots that are associated with living Spartina sp. marsh plants. The "live" roots and saturated mud indicate recent accumulation of both organic and clastic sediments. These same muddy sediments with large roots are absent from the tops of cores MB 01, MB 02, MB 03, MB 04, and MB 05, indicating that the most recent marsh sediments were either not deposited, were eroded, or were winnowed at the open-water sites. Below the most recent marsh deposits are black peat deposits with abundant fibrous roots that contain some dispersed mud. Total thickness of the peat and organic-rich mud facies ranges from $129 \mathrm{~cm}$ (MB 06) to $208 \mathrm{~cm}$ (MB 07). 


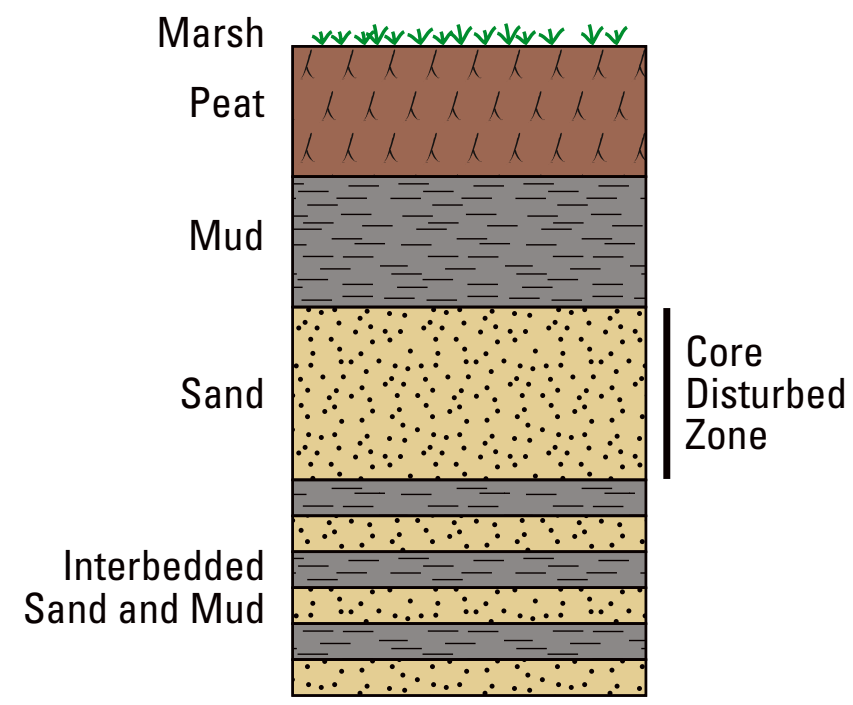

Figure 6. Generalized core profile showing the stratigraphic position of shallow deltaic sediments of the Lafourche subdelta.

In most of the cores, the peat and organic-rich sediments are in gradational contact with, or alternate with, thin beds of underlying olive gray mud containing roots. The top of the shallowest distinct mud bed is identified as the last significant flooding event (Table 2), whereas the base of the deepest distinct peat bed is identified as the first significant marsh surface. The initial marsh surface can be either a gradational or abrupt contact with the underlying massive mud.

The second sedimentary facies is brown to dark olive gray mud with abundant individual root traces. The root traces become less abundant with depth. The overall appearance of this facies is massive probably because of extensive bioturbation. The massive mud grades downward into the underlying sand and silty sand facies.

The next facies consists of light olive gray very fine-grained sand and silty sand that is saturated with water. The sand does not contain roots, although it may contain rare shell fragments, and the overall appearance may be faintly laminated, massive, or distorted. This facies consistently shows the most sediment deformation (Fig. 6). The sand and silty sand facies may be in sharp or gradational contact with the underlying alternating sand and mud facies.

The deepest stratigraphic horizon penetrated by the vibracores (Fig. 6) is alternating thin beds or laminations of light olive gray mud and very fine-grained sand. Some of the mud beds have a distinct light yellowish tan color. In most cores these alternating layers are distinct and the contacts are horizontal, which suggests that this part of the core is undisturbed.

\section{Interpreted Depositional Events}

The cored sediments represent an upward-coarsening and upward-fining aggradational stratigraphic succession that is typical of progradational deltaic deposits. The composition, arrangement, and thickness of the deltaic facies are similar to those illustrated by Frazier (1967) for prodelta, delta front, and delta plain peat deposits of the San Bernard lobe of the Mississippi 
delta. The progradational stratigraphic architecture at Madison Bay was probably associated with delta lobe construction by the Bayou Terrebonne distributary of the Lafourche subdelta lobe (Frazier, 1967). The vertical stacking of sedimentary facies records shoaling of a shallow interdistributary water body and eventual establishment of a subaerial marsh that persisted and aggraded for at least several hundred years. According to radiocarbon dates that help constrain the period of delta lobe deposition, the subdelta containing Madison Bay was initiated about 1200 years ago and the moderately thick delta plain peat recovered in the vibracores formed about 400 years ago (Frazier, 1967). The interbedded sand and mud facies, penetrated in the deepest cores (MB 03, MB 06, MB 07, MB 08, MB 10) represents the prodelta deposits that grade upward into the silty sand and homogeneous sand of the delta front deposits. The overlying gray mud and peat deposits represent the delta plain subenvironment. Alternating organic-rich mud, gray clay, and peat near the tops of most cores reflect the balance between sediment supply and relative sea-level rise as the first significant marsh was established and then buried by subsequent flooding. The deepest organic-rich zone represents the initial marsh whereas the shallowest gray clay represents the last (youngest) flooding event. Re-colonization of marsh plants promoted renewed marsh development that eventually survived until today. Episodic sedimentation in the delta plain marshes can result from overbank flooding of the distributary or from elevated water in the bays and Gulf of Mexico (storm surge). None of the cores exhibit thin $(2-3 \mathrm{~cm})$ discrete mud layers near the surface that could be interpreted as storm deposits (Cahoon et al., 1995). Instead, the flooding events tend to be at least $5 \mathrm{~cm}$ thick and stratigraphically near the contact with the underlying flood basin muds. This evidence suggests that the flooding events were associated with overbank flooding probably from the nearby distributary channels.

Organic-rich sediments above the last flooding event are thicker in core 1 than in core 7 even though core 1 was taken from an open water location. This indicates a potentially greater original thickness of marsh sediments in MB 01 and suggests that there has been only minor erosion of the most recent marsh deposits at the MB 01 site. Examination of a 1990 aerial photograph shows that MB 01 was located near a marsh tidal channel and the greater thickness of organic sediments is probably a streamside affect. At the same time, all the other cores were located within the interior marsh and away from any obvious streamside affects. By 1990 the site for MB 04 had already converted to open water (Fig. 3).

\section{SUBSIDENCE AND EROSION AT MADISON BAY}

At most vibracoring sites, the core barrel penetrates deeper than the length of sediment that is recovered in the core barrel. The difference between core depth and recovered core length is commonly reported as sediment compaction, although a more accurate definition of the difference is core shortening (Morton and White, 1997). Core shortening is estimated in the field by measuring how far the sediment in the core barrel is below the adjacent sediment surface (Table $3)$. After the core is opened, the stratigraphic intervals that are influenced by core shortening can be determined visually by identifying the zones of sediment disturbance (Fig. 6 and Appendix 
A). The degree of sediment deformation can be determined by comparing the stratigraphic contacts and laminae with actual or inferred horizontal planes across the core. The horizontal planes represent the configuration of undisturbed sediments. Some zones of disturbed sediments are also identified because they occur between zones of undisturbed sediments (MB 08, Appendix A). Bending of stratigraphic contacts as a result of frictional drag along the core barrel (MB 07, Appendix A) and contortion of sediment laminae (MB 01, Appendix A) are useful criteria for recognizing the zones of sediment disturbance and core shortening. In the cores from Madison Bay, the zones of greatest sediment disturbance are consistently below the contact between firm clay with relatively low water content and muddy sand with relatively high water content (Fig. 6). The frictional resistance of the firm clay causes liquifaction of the silty sand and core bypassing as the relatively stiff mud pushes some of the liquefied sand aside and it is not recovered in the core barrel. Because the zones of disturbed sediments are 2 to $3 \mathrm{~m}$ below the tops of the cores, the magnitudes of core shortening (Table 3) do not influence the estimates of erosion and subsidence at each coring site.

The surficial erosion and differential subsidence within the marsh interior can be estimated by comparing the elevations (Table 3 ) and vertical offsets (Table 4) of sediment surfaces and stratigraphic contacts that can be correlated between adjacent core pairs (Table 2, Fig. 7). The relative subsidence and erosion between marsh and open-water cores assumes that marsh sediment thickness and stratigraphic positions of correlation markers are uniform over short horizontal distances (tens of meters). The amount of erosion at the open-water core site is equal to the difference in marsh sediment thickness between the open-water core and the adjacent marsh core. The amount of subsidence at the open-water core is equal to the elevation difference between the correlated stratigraphic marker between the two adjacent cores. To be precise, the erosion and subsidence estimates must equal the vertical displacement between the cores (Table 4). This technique provides a minimum estimate of total subsidence because there is no measurement of the absolute amount of historical subsidence of the marsh surface relative to some

\begin{tabular}{|l|l|l|l|l|l|l|}
\hline \multicolumn{1}{|c|}{$\begin{array}{c}\text { Paired } \\
\text { Cores }\end{array}$} & $\begin{array}{c}\text { Marsh } \\
\text { Core } \\
\text { Elev. }(\mathrm{cm})\end{array}$ & $\begin{array}{c}\text { Water } \\
\text { Core } \\
\text { Elev. }(\mathrm{cm})\end{array}$ & $\begin{array}{c}\text { Vertical } \\
\text { Offset } \\
(\mathrm{cm})\end{array}$ & $\begin{array}{c}\text { Erosion } \\
(\mathrm{cm})\end{array}$ & $\begin{array}{c}\text { Subsidence } \\
(\mathrm{cm})\end{array}$ & $\begin{array}{c}\text { Ave. Subs. } \\
\text { Rate } \\
(\mathrm{mm} / \mathrm{yr})\end{array}$ \\
\hline MB 07 \& 01 & 18.3 & -51.3 & 70 & 02 & 68 & 23 \\
\hline MB 08 \& 02 & 14.0 & -64.8 & 79 & 26 & 53 & 18 \\
\hline MB 09 \& 03 & 11.0 & -82.3 & 93 & 31 & 62 & 21 \\
\hline MB 10 \& 06 & 24.4 & -63.6 & 88 & 24 & 64 & 21 \\
\hline MB 04 & (corr/03) & -114.2 & 32 & 33 & 92 & 30 \\
\hline MB 05 & (corr/03) & -98.2 & 16 & 34 & 75 & 25 \\
\hline
\end{tabular}

Table 4. Core elevations adjusted to the water-level datum of the Cocodrie tide gauge (see Table 3), vertical offset between core pairs (see Table 3), estimated magnitudes of erosion and subsidence, and average rates of subsidence assuming a 30 -year period. 
A.

$\begin{array}{ll}\text { MB07 } & 39 \mathrm{~m} \\ & \mathrm{MB01}\end{array}$

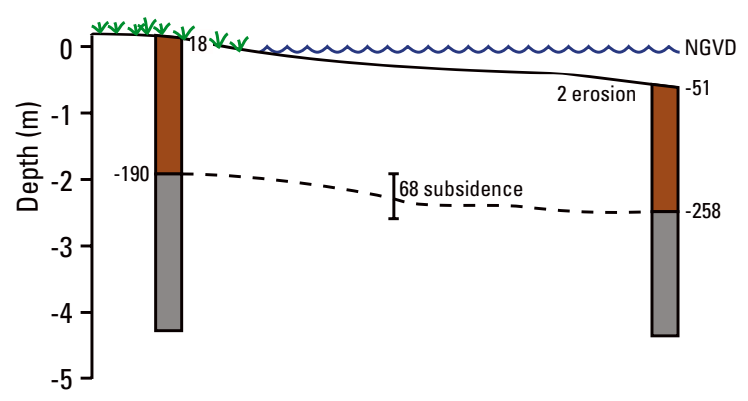

C.
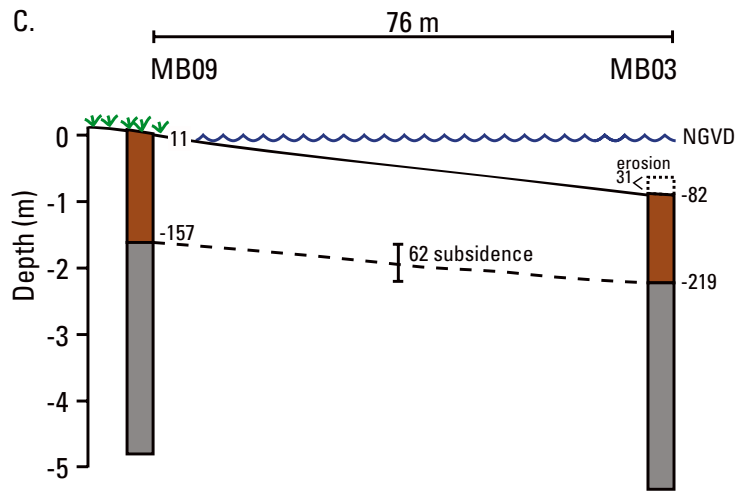

B.
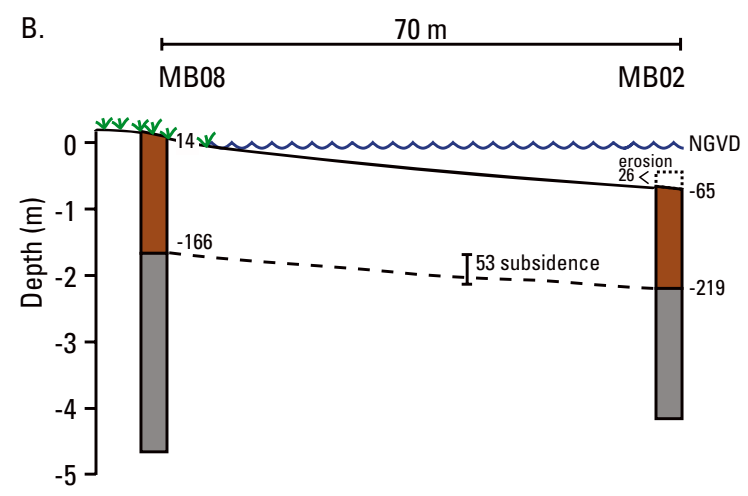

D.

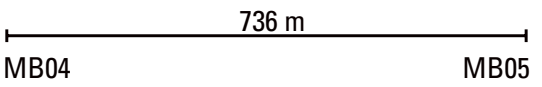

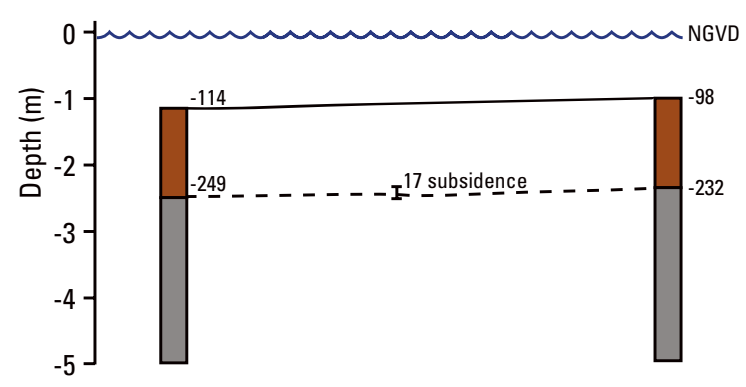

E.

$68 \mathrm{~m}$
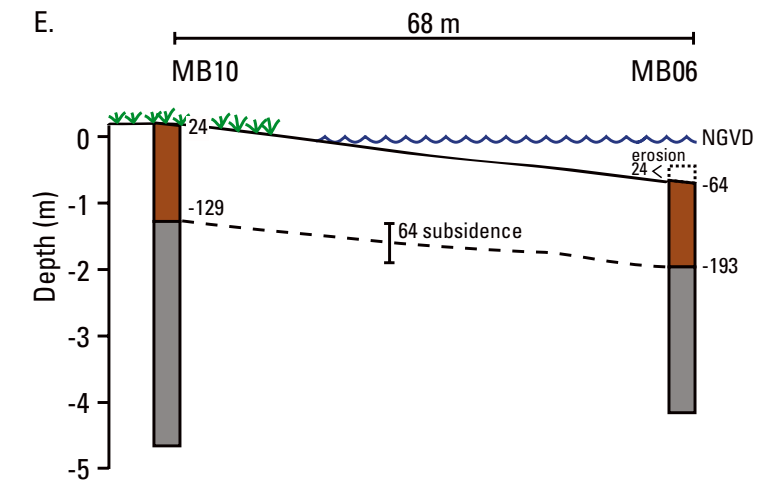

Figure 7. Stratigraphic correlations for marsh and open water core pairs illustrate the magnitude of subsidence and wetland erosion (in $\mathrm{cm}$ ) at the Madison Bay wetland loss hotspot. Locations shown in Figures 2 and 3.

standard vertical datum. Stated another way, the marsh sediments preserved beneath Madison Bay have subsided more than the adjacent subaerial marsh sediments, but the entire area including the subaerial marsh sediments have subsided some unknown amount.

Erosion and subsidence estimates for core pairs 08-02, 03-09, and 06-10 are excellent because the differences between correlative stratigraphic horizons are only a few $\mathrm{cm}$ (Table 2). Erosion and subsidence estimates are less precise for core pairs 01-07 and 04-05 because stratigraphic correlations and interval thicknesses are not uniform. Although several different stratigraphic horizons were correlated between core pairs, the elevation of the first marsh was used to 
estimate the site-specific magnitudes of subsidence and erosion because it was identified in each core (Table 2).

The amount of vertical erosion at the submerged sites varies from 2 to $34 \mathrm{~cm}$ (Table 4 ). Erosion is the least at MB 01, which may be the most recent site to become submerged. The estimated magnitude of incremental subsidence for each core pair ranges between 53 and $92 \mathrm{~cm}$ (Table 4). The estimated subsidence is greatest at MB 04, which is the site that has been open water the longest (see Fig. 3). Some of the most recent muddy marsh sediments recovered in the tops of cores MB 07, MB 08, MB 09, and MB 10 may have never been deposited at the adjacent open water sites. This would be true if (1) the most recent marsh sedimentation occurred after the rapid expansion of open water in 1969, and (2) the new marsh sediment was imported from the submerged marsh sediments. These requisite conditions appear to be confirmed by field measurements of others. Cahoon et al. (1999) reported high rates of sedimentation in the marshes around Madison Bay between and 1992 and 1997. Murray et al. (1993) described how winter storms resuspended bay-bottom sediments near Madison Bay and delivered the sediment to the marsh surface. Inclusion of excess marsh sediment thickness in the calculations would overestimate the total vertical offset and the amount of erosion but it would not influence the estimate of subsidence.

The estimates of erosion and subsidence at each coring site can be used to explain the general water depths in Madison Bay. Water depths are shallow around the margins of the bay where erosion has been minimized and the water is relatively deep where both sediment erosion and land subsidence are greatest (cores 4 and 5, Table 4). Assuming that water depths in Madison Bay average about $1 \mathrm{~m}$ (Fig. 5) and marsh elevations average about $0.15 \mathrm{~m}$ (Table 4) then about two thirds of the water depth is attributable to subsidence and one third is attributable to erosion of the submerged organic marsh sediments (Table 4).

\section{GEOLOGICAL AND HISTORICAL RATES OF SUBSIDENCE}

Average subsidence rates compiled for the Madison Bay area from various sources clearly show that the historical rates of subsidence are an order of magnitude greater than the geological rates of subsidence (Table 5). Subsidence rates averaged for hundreds or thousands of years are based on radiocarbon dates and depths of peat samples from sediment cores. The peat sample analyzed by Frazier (1967) is from a core taken in the marsh that is now open water and part of the Madison Bay wetland loss area. The peat sample analyzed by Roberts (1994) is from a core taken near Cocodrie. That core location is geographically near and geologically equivalent (downthrown side of the Golden Meadow fault zone) to the Madison Bay wetland loss area. Average subsidence rates associated with Holocene deltaic sediments older than about 500 years are only a few mm/yr (Penland et al., 1988). This general estimate agrees well with site specific subsidence rates calculated for the Madison Bay core $(1.4 \mathrm{~mm} / \mathrm{yr})$ of Frazier (1967) and estimated by Roberts et al. (1994) for the Cocodrie core $(2.7 \mathrm{~mm} / \mathrm{yr})$. 


\begin{tabular}{|l|l|l|l|}
\hline \multicolumn{1}{|c|}{ Source of Estimate } & \multicolumn{1}{c|}{ Period } & Ave. Subs. Rate & \multicolumn{1}{c|}{ Reference } \\
\hline $\mathrm{C}^{14}$ core P-1-90 & $4740 \mathrm{BP}$ & $2.7 \mathrm{~mm} / \mathrm{yr}$ & Roberts et al. (1994) \\
\hline $\mathrm{C}^{14}$ peat sample 2067 & $425 \mathrm{BP}$ & $1.4 \mathrm{~mm} / \mathrm{yr}$ & Frazier (1967) \\
\hline Houma tide gauge & $1946-1962$ & $0.7 \mathrm{~mm} / \mathrm{yr}$ & Penland et al. (1988) \\
\hline Houma tide gauge & $1962-1982$ & $19.4 \mathrm{~mm} / \mathrm{yr}$ & Penland et al. (1988) \\
\hline Petit Caillou relevel line & $1966-1993$ & $9.3 \mathrm{~mm} / \mathrm{yr}$ & Morton et al., 2002 \\
\hline SET measurements & $1992-1997$ & $22 \mathrm{~mm} / \mathrm{yr}$ & Cahoon et al., 1999 \\
\hline Cores and water levels & $1969-1999$ & $23 \mathrm{~mm} / \mathrm{yr}$ & This study \\
\hline
\end{tabular}

Table 5. Average geological and historical rates of subsidence for the Terrebonne delta plain region near Madison Bay.

Historical rates of subsidence near Madison Bay can be estimated using vertical offsets of core pairs, water level records, surface elevation table (SET) measurements, and releveling surveys (Table 5). Estimating magnitudes of subsidence from core pairs is relatively uncomplicated, but calculating average rates of subsidence is made difficult because the period of recorded subsidence is not precisely known. Comparison of the 1990 and 2000 aerial photographs (Figs. 2 and 3) shows that the marsh at cores MB 01, MB 02, MB 03, MB 05, and MB 06 was submerged in less than 10 years. However it is unknown if the total differential subsidence measured between core pairs (Table 4) occurred in that brief period or over a longer period. Calculated subsidence rates are exceptionally high (53 to $92 \mathrm{~mm} / \mathrm{yr}$ ) if the total vertical displacement is assigned to the 10 year period of submergence. However the average rate of subsidence calculated from the Madison Bay cores for the $30 \mathrm{yr}$ period (1969-1999) corresponding to the most rapid wetland loss (Reed, 1995; Cahoon et al.,1999) is $23 \mathrm{~mm} / \mathrm{yr}$ (Tables 4 and 5). This compares well with marsh subsidence rates measured by Cahoon et al. (1999) at Bayou Chitigue in the southeast corner of the Madison Bay hotspot $(22 \mathrm{~mm} / \mathrm{yr})$ and the relative rise in sea level recorded at the Houma tide gauge between 1962 and 1982 (19.4 mm/yr). The highest local subsidence rate derived from the NOAA Bayou Petit Calliou relevel line $(9.3 \mathrm{~mm} / \mathrm{yr})$ coincides spatially with the Madison Bay wetland loss hotspot and with the downthrown side of the Golden Meadow fault zone. It is uncertain why the subsidence rate for the relevel line between 1966 and 1993 is approximately half that of the other estimates for the same approximate period.

\section{DISCUSSION AND CONCLUSIONS}

Several lines of converging evidence indicate that rapid subsidence and conversion of wetlands to open water near Madison Bay were caused primarily by reduction of surface elevations associated with hydrocarbon production and probable fault reactivation. The wetland loss hotspot at Madison Bay is surrounded by wells extracting hydrocarbons from deep subsurface 


\begin{tabular}{|l|l|l|l|l|}
\hline \multicolumn{1}{|c|}{ Field } & Discovery & \multicolumn{1}{c|}{ Cum. gas } & \multicolumn{1}{c|}{ Cum. oil } & \multicolumn{1}{c|}{ Cum. water } \\
\hline Lirette & 1937 & $1.3 \mathrm{Tcf}$ & $18 \mathrm{MMbbl}$ & $59 \mathrm{MMbbl}$ \\
\hline Lapeyrouse & 1941 & $624 \mathrm{Bcf}$ & $18 \mathrm{MMbbl}$ & $39 \mathrm{MMbbl}$ \\
\hline Bay Baptiste & 1938 & $136 \mathrm{Bcf}$ & $2.5 \mathrm{MM} \mathrm{bbl}$ & $17 \mathrm{MM} \mathrm{bbl}$ \\
\hline
\end{tabular}

Table 6. Year of discovery and subsequent cumulative fluid production for the three hydrocarbon fields near the Madison Bay hotspot of wetland loss. Production data from the Louisiana Department of Natural Resources. Field locations shown on Figure 1.

reservoirs. Lapeyrouse, Lirette, and Bay Baptiste (Fig. 1) are the fields closest to Madison Bay that together have produced large volumes of gas, oil and formation water (Table 6, Fig.8A). All three fields produced subsurface fluids at low to moderate rates in the 1940s and 1950s. Annual production accelerated in the 1960s and peaked in the early 1970s (Fig. 8, Morton et al., 2002).
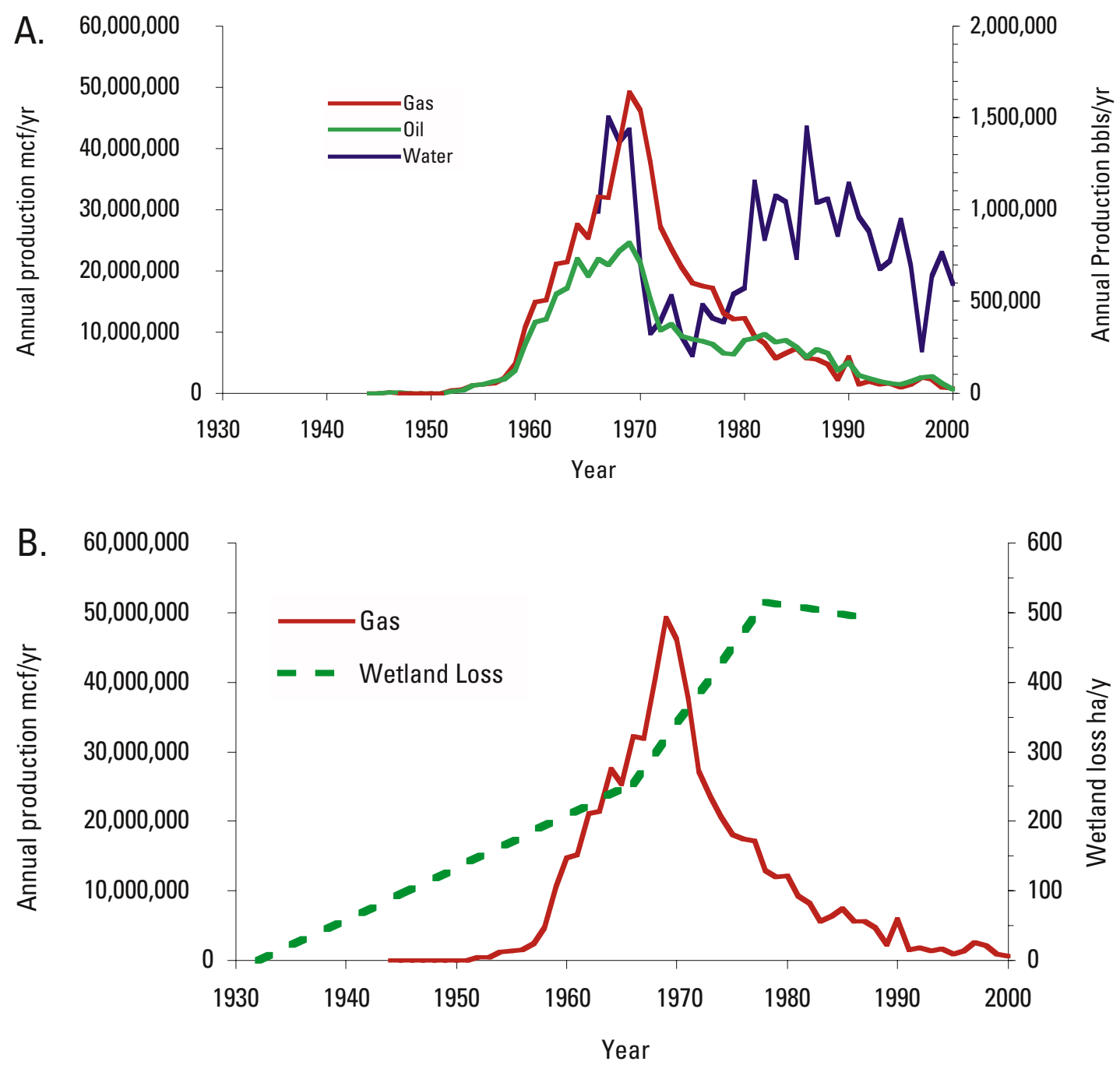

Figure 8. Temporal comparison of $A$. annual volumes of fluid produced from the Lapeyrouse field (data from the Louisiana Department of Natural Resources) and B. wetland losses in the Dulac quadrangle (data from Britsch and Dunbar, 1993). 
The combined fluid production from all three fields exceeded 2 trillion $\mathrm{ft}^{3}$ of gas and 154 million bbls of oil and water (Table 6). This large-volume fluid production was accompanied by rapid reductions in formation pressure that typically dropped as much as 4000 to 5000 psi in normally pressured reservoirs (Morton et al., 2002).

Releveling surveys along Bayou Petit Caillou (Fig. 1) provide compelling evidence that regional subsidence and wetland loss were at least partly induced by hydrocarbon production. They show that the broad regional zone of historical wetland losses, (Fig. 1) essentially coincided with the zones of maximum land surface subsidence, which coincide with the producing fields and faults (Morton et al., 2002). Additional evidence of subsidence comes from aerial photographs of the region (Fig. 1) that show that widths of the subaerial levees along Bayou Terrebonne and Bayou Petit Caillou are wider both north (upstream) and south (downstream) of the zone of greatest wetland loss. Morton et al. (2002) concluded that large decreases in reservoir pressure likely induced subsidence and reactivated a subsurface fault in the Lapeyrouse field that has displacement and orientation that are consistent with the pattern of wetland loss near Madison Bay.

The most detailed and comprehensive mapping of wetland loss in coastal Louisiana was conducted by Britsch and Dunbar (1993), who used aerial photographs and topographic maps from 1930, 1958, 1974, 1983, and 1990 to document wetland changes for the intervening four periods. Although the periods are not equal in duration, the sequential analysis of historical data shows that (1) rates of loss initially accelerated then decelerated, and (2) more than half of the documented wetland losses occurred between 1958 and 1974 (Britsch and Dunbar (1993). The period of greatest wetland loss also corresponds to the period of greatest hydrocarbon production from fields in south Louisiana (Fig. 8). The period of accelerated production and wetland loss also falls within the period of rapid subsidence documented by various methods (Table 5).

The marsh cores provide additional evidence of recent environmental change in the Madison Bay wetlands. The relatively thick peat in all the cores record a prolonged uniform depositional history of slow delta plain subsidence and attendant slow aggradation of peat without significant disruption by prolonged flooding events. These organic-rich sediments that accumulated as a result of natural processes are in contrast to the uppermost organic-rich muds of the modern marsh that record frequent flooding and attendant rapid accumulation of muddy sediments as subsidence accelerated and elevations decreased.

The observed wetland losses at Madison Bay generally progressed from north to south (Reed, 1995). That direction of differential subsidence is consistent with (1) the vertical offset of cores (compare subsidence at cores 4 and 5 with 2 and 3) and down-to-the-south displacement of the spur fault of the Golden Meadow fault zone that probably intersects the surface where wetland loss is greatest (Kuecher et al., 2001).

Many causes of regional wetland loss in coastal Louisiana have been identified in previous studies on the basis of theory, field observations, and modeling (Table 7). Although all of these explanations have merit and are applicable at some locations, none of them are able to adequately explain the observed rapid acceleration and then sudden decline in wetland loss. For 


\begin{tabular}{|l|l|l|}
\hline \multicolumn{1}{|c|}{ Category } & \multicolumn{1}{|c|}{ Process } & \multicolumn{1}{c|}{ Reference } \\
\hline Delta cycle & Construction and destruction & Wells and Coleman, 1987 \\
\hline & Sediment compaction & Suhayda et al., 1993, Kuecher et al., 1993 \\
\hline Biogeochemical & Shoreline or marsh erosion & Adams et al., 1978; Nyman et al., 1994 \\
& Saltwater intrusion & $\begin{array}{l}\text { Gosselink et al., 1977; DeLaune and Pezeshki, } \\
1994\end{array}$ \\
\hline & Waterlogging and sulfide conc. & Mendelssohn and McKee, 1988 \\
\hline Human activities & Herbivory & Gosselink, 1984 \\
\hline & Canee construction & Craig et al., 1979 \\
\hline & Failed reclamation projects & Scaife et al., 1983; Turner, 1997 \\
\hline
\end{tabular}

Table 7. Previously reported causes of regional wetland losses in coastal Louisiana

example, rates of subsidence associated with natural compaction of deltaic sediments decrease with time because the water expelled from the sediments is depleted. The commonly cited biogeochemical causes of wetland loss (Table 7) are all symptomatic of marsh submergence and although they explain the physiological reasons for marsh die-back, they do not address the fundamental mechanism(s) that caused rapid submergence. The most commonly cited human activities that alter wetland hydrology and reduce sediment supply (levees, canals, reclamation projects) also are unable to explain the history of wetland losses, especially the well-documented decreases in recent periods.

The compelling evidence presented in this report indicates that the rapid wetland loss at the Madison Bay hotspot was caused by subsidence and probably fault reactivation induced by hydrocarbon production. However, it is uncertain how much of the regional wetland loss in coastal Louisiana can be attributed to regional depressurization related to long-term, largevolume oil and gas production. Also it is unclear if the rates of subsidence induced by hydrocarbon production have diminished since the rates of fluid withdrawal have dramatically declined (Fig. 8). It may be that after the areas initially subside rapidly that the subsurface stresses achieve a new equilibrium and the surficial adjustments (subsidence and fault movement) are diminished. Reduced subsidence rates would have a profound influence on the designs of projects intended to restore wetland resources in the delta plain. Answering these important questions and their implications with regard to wetland loss mitigation will require additional research. 


\section{ACKNOWLEDGEMENTS}

We thank Del Britsch and the New Orleans District Army Corps of Engineers for collecting the vibracores in Madison Bay. Betsy Boynton prepared the report illustrations and layout. Scientific and editorial reviews were provided by Don Cahoon and Jeff Williams.

\section{REFERENCES}

Adams, R.D., Banas, P.J., Baumann, R.H., Blackmon, J.H., and McIntire, W.G., 1978, Shoreline erosion in coastal Louisiana: Inventory and assessment: Louisiana State University Center for Wetland Resources, $139 \mathrm{p}$.

Boesch, D.F., Josselyn, M.N., Mehta, A.J., Morris, J.T., Nuttle, W.K., Simenstad, C.A., and Swift, D.J.P., 1994, Scientific assessment of coastal wetland loss restoration and management in Louisiana: Journal of Coastal Research Special Issue No. 20, 103 p.

Britsch, L.D., and Dunbar, J.B., 1993, Land-loss rates Louisiana coastal plain: Journal of Coastal Research, v. 9, p. 324-338.

Cahoon, D.R., Reed, D.J., and Day, J.W. Jr., 1995, Estimating shallow subsidence in microtidal salt marshes of the southeastern United States: Kaye and Barghoorn revisited: Marine Geology, v. 128, p. $1-9$.

Cahoon, D.R., Day, J.W. Jr., and Reed, D.J., 1999, The influence of surface and shallow subsurface soil processes on wetland elevation: A synthesis: Current Topics in Wetland Biogeochemistry, v. 3, p. 7288.

Coleman, J.M., and Roberts, H.H., 1989, Deltaic coastal wetlands: Geologie en Mijnbouw, v. 68, p. 1-24.

Craig, N.J., Turner, R.E., and Day, J.W., Jr., 1979, Land loss in coastal Louisiana (USA): Environmental Management, v. 3, p. 133-144.

Day, R.H., Holz, R.K., and Day, J.W., 1990, An inventory of wetland impoundments in the coastal zone of Louisiana, USA: Historical trends: Environmental Management, v. 14, p. 229-240.

Day, J.W., Reed, D.J., Suhayda, J.N., Kemp, G.P., Cahoon, D.R., Boumans, R.M., and Latif, N., 1994, Physical processes of marsh deterioration, in Roberts, H.H. (ed.), Critical physical processes of wetland loss: Louisiana State University Final Report 1988-1994 submitted to U.S. Geological Survey, p. 5.1-5-40.

Day, J.W., Shaffer, G.P., Britsch, L.D., Reed, D.J., Hawes, S.R., and Cahoon, D.R., 2000, Pattern and process of land loss in the Mississippi delta: A spatial and temporal analysis of wetland habitat change: Estuaries, v. 23, p. 425-438.

DeLaune, R.D., and Pezeshki, S.R., 1994, The influence of subsidence and saltwater intrusion on coastal marsh stability: Louisiana Gulf coast, USA: Journal of Coastal Research Special Issue 12, p. 77-89. 
DeLaune, R.D., Nyman, J.A., and Patrick, W.H. Jr., 1994, Peat collapse, ponding, and wetland loss in a rapidly submerging coastal marsh: Journal of Coastal Research, v. 10, p. 1021-1030.

Frazier, D.E., 1967, Recent deltaic deposits of the Mississippi River: Their development and chronology: Transactions Gulf Coast Association of Geological Societies, v. 17, p.287-315.

Gagliano, S.M., Myer-Arendt, K.J., and Wicker, K.M., 1981, Land loss in the Mississippi River deltaic plain: Transactions Gulf Coast Association of Geological Societies, v. 31, p. 295-306.

Gosselink, J.G., 1984, The ecology of delta marshes of coastal Louisiana; A community profile: U.S. Fish and Wildlife Service Biological Services Program, FWS/OBS-84/09, 134p.

Gosselink, J.G., and Baumann, R.H., 1980, Wetland inventories: wetland loss along the United States coast: Zeitschrift fur Geomorphologie v. 34, p. 173-187.

Gosselink, J.G., Hopkinson, C.S., and Parrondo, R.T., 1977, Common marsh plant species of the Gulf Coast area: Vol. II Growth dynamics: U.S. Army Corps of Engineers, Waterways Exp. Station, Vicksburg Miss., Tech. Rept. D-77-44. 37 p.

Kuecher, G.J., Chandra, N., Roberts, H.H., Suhayda, J.H., Williams, S.J., Penland, S., and Autin, W.J., 1993, Consolidation settlement potential in south Louisiana; Coastal Zone '93, p. 1197-1214.

Kuecher, G.J., Roberts, H.H., Thompson, M.D., and Matthews, I., 2001, Evidence for active growth faulting in the Terrebonne delta plain, south Louisiana: Implications for wetland loss and the vertical migration of petroleum: Environmental Geosciences, v. 8, p. 77-94.

Leibowitz, S.G., and Hill, J.M., 1987, Spatial analyses of Louisiana coastal land loss, in Turner, R.E., and Cahoon, D.R. (eds.), Causes of Wetland Loss in the Coastal Central Gulf of Mexico: Minerals Management Service OCS Study MMS87-0120, v. II Technical Narrative, p. 331-355.

Mendelssohn, I.S., and McKee, K.L., 1988, Spartina alterniflora die-back in Louisiana: Time-course investigation of soil waterlogging effects: Journal of Ecology, v. 76, p. 509-521.

Morton, R. A., and White, W. A., 1997, Characteristics of and corrections for core shortening in unconsolidated sediments: Journal of Coastal Research, v. 13, p. 761-769.

Morton, R.A., Buster, N.A., and Krohn, M. D., 2002, Subsurface controls on historical subsidence rates and associated wetland loss in southcentral Louisiana: Transactions Gulf Coast Association of Geological Societies, v. 52, p.

Murray, S.P., Walker, N.D., and Adams, C.E., Jr., 1993, Impacts of winter storms on sediment transport within the Terrebonne Bay marsh complex, In Laska, S. and Puffer, A. (eds.) Coastlines of the Gulf of Mexico: American Society of Civil Engineers, Ney York, p. 56-70.

Nyman, J.A., DeLaune, R.D., Roberts, H.H., and Patrick, W.H. Jr., 1993, Relationship between vegetation and soil formation in a rapidly submerging coastal marsh: Marine Ecology Progress Series, v.96, p. 269-279. 
Nyman, J.A., Carloss, M., DeLaune, R.D., and Patrick, W.H. Jr., 1994, Erosion rather than plant dieback as the mechanism of marsh loss in an estuarine marsh: Earth Surface Processes and Landforms, v. 19, p. 69-84.

Penland, S., Ramsey, K.E., McBride, R.A., Mestayer, J.T., and Westphal, K.A., 1988, Relative sea-level rise and delta-plain development in the Terrebonne Parish region: Louisiana Geological Survey, Coastal Geology Technical Report No. 4, 121 p.

Penland, S., Wayne, L., Britsch, L.D., Williams, S.J., Beall, A.D., and Butterworth, V.C., 2000, Process classification of coastal land loss between 1932 and 1990 in the Mississippi River delta plain, southeastern Louisiana: U.S. Geological Survey Open File Report 00-418, map with text.

Reed, D.J. (ed.), 1995, Status and trends of hydrologic modification, reduction in sediment availability, and habitat loss/modification in the Barataria-Terrebonne estuarine system: Barataria-Terrebonne National Estuary Program Publication No. 20, 338 p.

Roberts, H.H. (ed.), 1994, Critical physical processes of wetland loss: Louisiana State University Final Report 1988-1994 submitted to U.S. Geological Survey.

Roberts, H.H., Bailey, A., and Kuecher, G.J., 1994, Subsidence in the Mississippi River delta - Important influences of valley filling by cyclic deposition, primary consolidation phenomena, and early diagenesis: Transactions Gulf Coast Association of Geological Societies, v. 44, p. 619-629.

Scaife, W.W., Turner, R.E., and Costanza, R., 1983, Coastal Louisiana recent land loss and canal impacts: Environmental Management, v. 7, p. 433-442.

Suhayda, J.N., 1987, Subsidence and sea level, in Turner, R.E., and Cahoon, D.R., eds. Causes of Wetland Loss in the Coastal Central Gulf of Mexico: Minerals Management Service OCS Study MMS87-0120, v. II Technical Narrative, p. 187-202.

Suhayda, J.N., Bailey, A., Roberts, H.H., Penland, S., and Kuecher, G.J., 1993, Subsidence properties of Holocene sediments; south Louisiana: Coastal Zone ‘93, p. 1215-1229.

Turner, R.E., and Cahoon, D.R. (eds.), 1988, Causes of Wetland Loss in the Coastal Central Gulf of Mexico: Minerals Management Service OCS Study MMS87-0120, v. II Technical Narrative,

Turner, R.E., 1997, Wetland loss in the northern Gulf of Mexico: Multiple working hypotheses: Estuaries, v. 20, p. 1-13.

Wells, J. T., and Coleman, J. M., 1987, Wetland loss and the subdelta life cycle: Estuarine, Coastal, and Shelf Science, v. 25, 111-125.

Williams, S.J., Penland, S., and Roberts, H.H., 1994, Processes affecting coastal wetland loss in the Louisiana deltaic plain: American Society of Civil Engineers Coastal Zone '93, p. 211-219. 


\section{APPENDIX A: CORE DESCRIPTIONS}




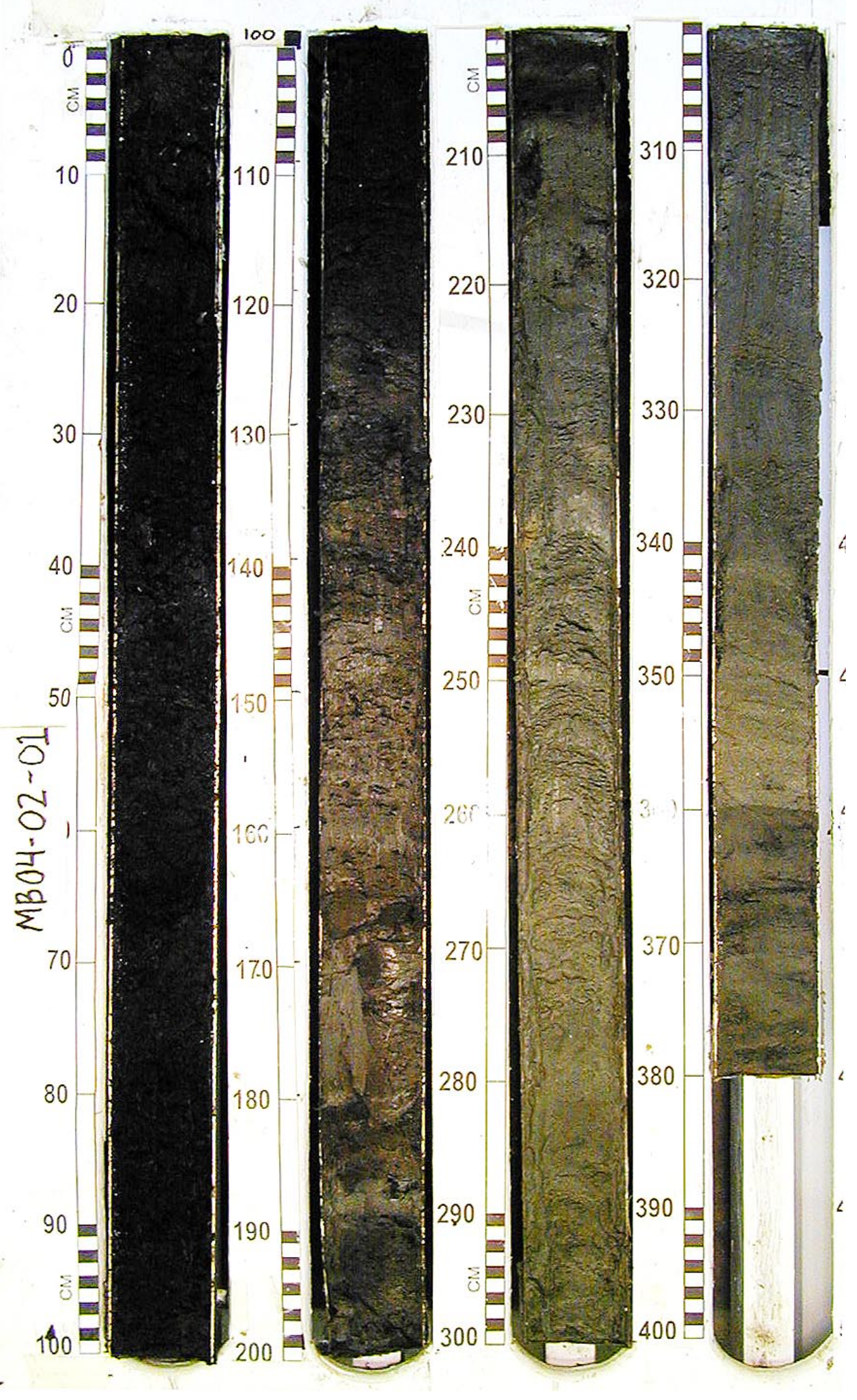


Location: Madison Bay, Terrebonne Parish, LA

Latitude N2920'20.14”'

Water depth $0.82 \mathrm{~m}$

Longitude W90³6'03.23”'

Date obtained 04/30/02

Length recovered $3.8 \mathrm{~m}$

Date described 05/21/02

$0-125 \mathrm{~cm}$

Black Organic Peat

Black marsh mat and abundant fibrous roots $>80 \%$ organics

Some clay with small silt content $~ 30-40 \%$

* sharp basal contact

125-208cm Brownish-Black Mud (5YR 2/1) to Dark Gray Mud (N3)

$60 \%$ silt $40 \%$ clay, $\sim 30-40 \%$ root traces

Massive

* sharp basal contact

208-326cm Olive Gray Mud (5Y 4/1)

Coarser grained than above section approximately $70 \%$ silt and $30 \%$ clay No root traces

Large root masses $\sim 3 \mathrm{~cm}$ long at $212 \mathrm{~cm}$

$277-290 \mathrm{~cm}$. very fine-grained sandy unit

Questionable small mica flakes and/or organics

* gradational contact

326-360cm Light Olive Gray Sand (5Y 5/2)

Mostly very fine-grained sand some silt present $\sim 25 \%$

Massive

No shells and no roots

* sharp basal contact

360-380cm Light Olive Gray Silty Sand (5Y 5/2)

Massive

Slightly darker than section above

Root trace or wood at $367 \mathrm{~cm}$ 


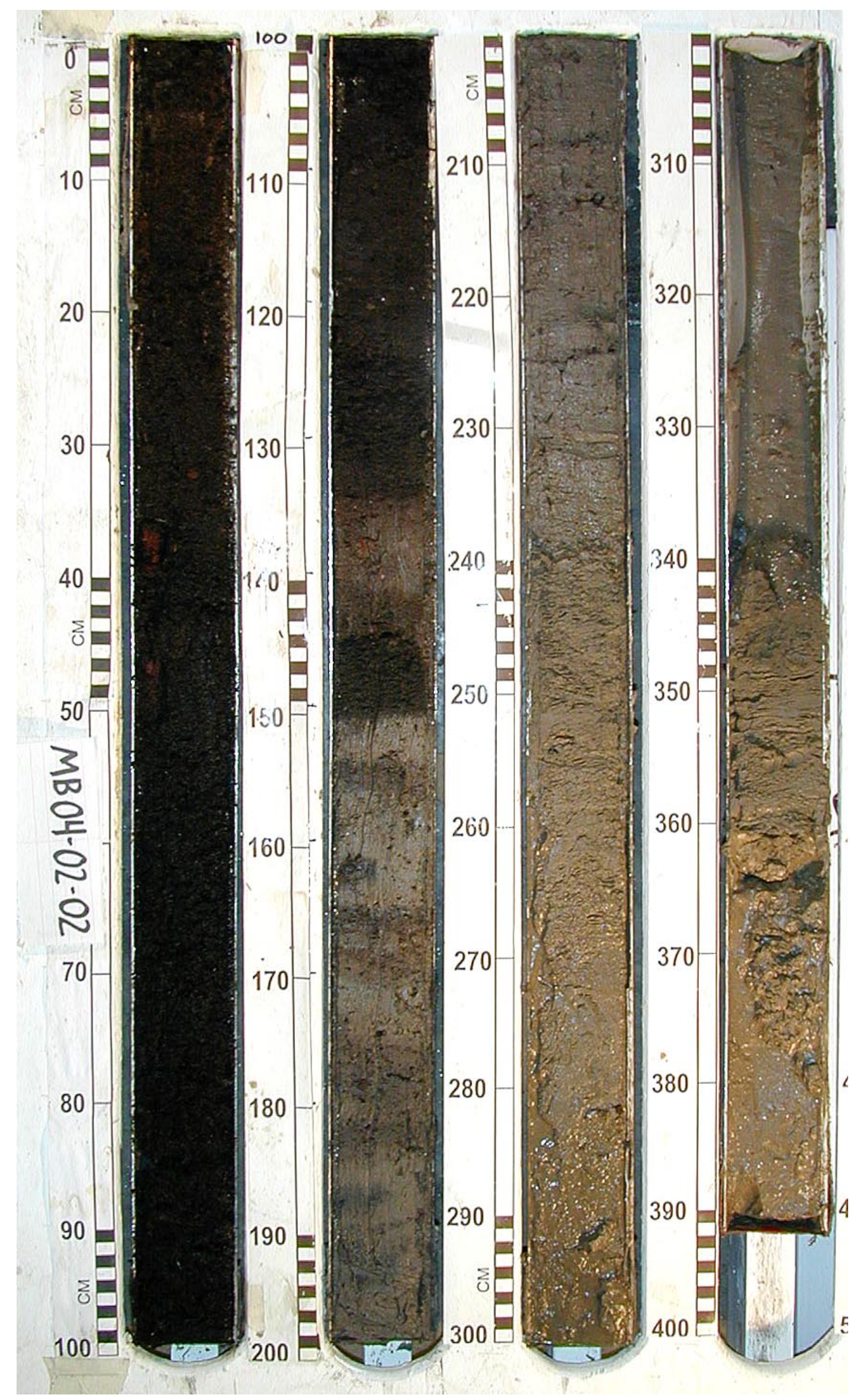


Location: Madison Bay, Terrebonne Parish, LA

Latitude N29²0’09.87'”

Water depth $0.98 \mathrm{~m}$

Date obtained 04/30/02
Longitude W90³4'48.79'

Length recovered $3.53 \mathrm{~m}$

Date described 05/29/02

$0-137 \mathrm{~cm}$

Black Organic Peat

Black marsh mat with $>80 \%$ fibrous roots, some large roots are $\sim 5 \mathrm{~cm}$ in length Rafted wood or large root $\sim 6 \mathrm{~cm}$ long and $2 \mathrm{~cm}$ wide at $38 \mathrm{~cm}$

* sharp contact

137-148cm Dark Olive Gray Mud (5Y 3/2) 30 to $40 \%$ rooting

* shart contact

$148-154 \mathrm{~cm} \quad$ Black Organic Peat

Black marsh mat $>80 \%$ fibrous roots, possibly compacted

* sharp contact

$154-240 \mathrm{~cm} \quad$ Olive Gray Mud (5Y 4/1)

Mud with $40 \%$ root traces, root traces become less abundant down the section then disappear near gradational contact at bottom.

Upper $\sim 45 \mathrm{~cm}$ contains darker more organic rich zones $\sim 4 \mathrm{~cm}$ thick

* gradational contact

240-353cm Light Olive Gray Muddy Sand (5Y 5/2)

Sand is very fine grained

No organics

Massive

May have had some alternating parallel laminations mud/sand 


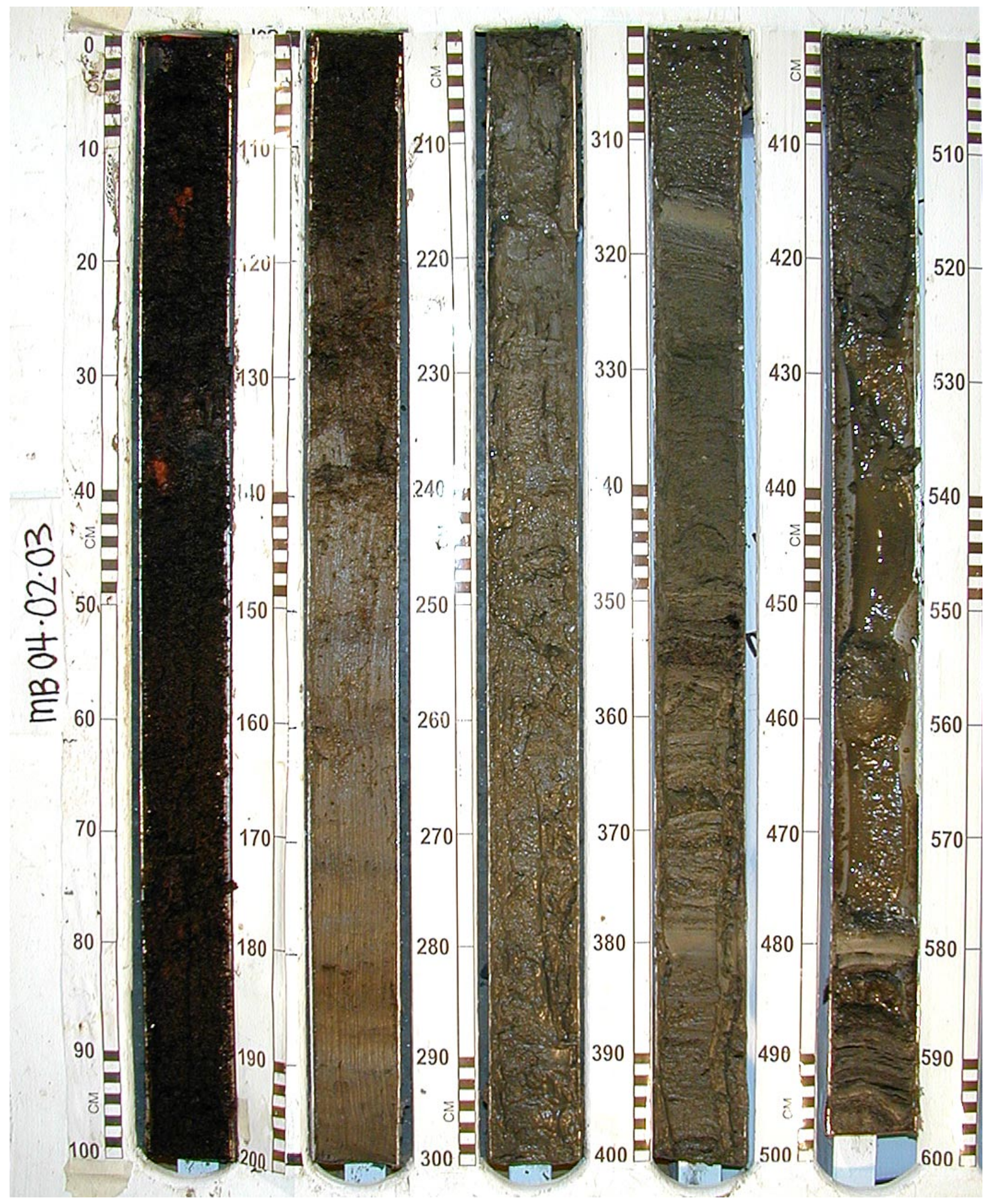


Core MB 04-02-03

Location: Madison Bay, Terrebonne Parish, LA

Latitude N29 $20^{\prime} 56.71^{\prime \prime}$

Water depth $1.16 \mathrm{~m}$

Longitude W90 $34^{\prime} 30.37^{\prime \prime}$

Date obtained 04/30/02

Length recovered $4.5 \mathrm{~m}$

Date described 06/04/02

$0-137 \mathrm{~cm}$

Black Organic Peat

Black marsh mat, fibrous roots

$>90 \%$ organics

Bottom $5 \mathrm{~cm}$ are more brown in color

* gradational contact

$137-200 \mathrm{~cm}$

Olive Gray Mud (5Y 3/2)

Mud $\sim 60 \%$ clay, $40 \%$ silt and $\sim 20-30 \%$ organic

* sharp contact

200-310cm Medium Olive Gray Silt

Silt with 20-30\% fine-grained sand and $\sim 10-20 \%$ mud

Massive appearing

2 possible mica flake clusters appearing at 268 and $301 \mathrm{~cm}$

* gradational contact

310-450cm Medium to Light Olive Gray Muddy Sand (5Y 5/2)

Parallel laminated fine-grained sand and silt

Clay content $\sim 10-20 \%$

Organic layer, or possibly wood, at $353-355 \mathrm{~cm}$

Deformation is present in section 


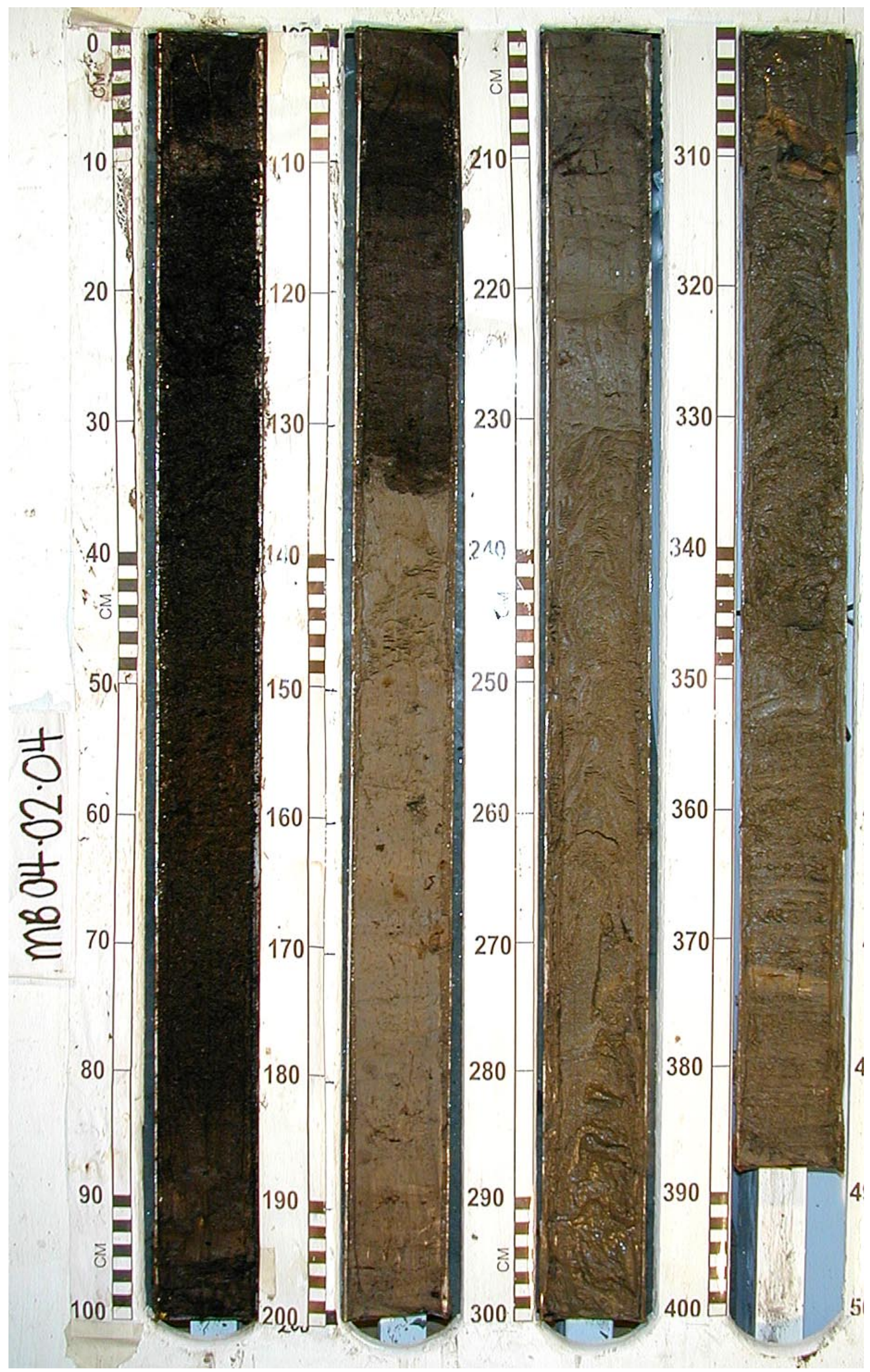


Core MB 04-02-04

Location: Madison Bay, Terrebonne Parish, LA

Latitude N2921'11.53'

Longitude W90³5'03.16"

Water depth $1.5 \mathrm{~m}$

Length recovered $3.89 \mathrm{~m}$

Date obtained 04/30/02

Date described 05/22/02

$0-90 \mathrm{~cm}$

Black Organic Peat

Fibrous root mass $>90 \%$, (submerged marsh mat)

Roots $\sim 2-4 \mathrm{~cm}$ long

* gradational contact

90-107cm Medium Olive Gray Mud (5Y 4/2)

Roots rare $\sim 15 \%$

Massive

* sharp contact

$107-135 \mathrm{~cm}$ Medium Olive Gray Peat (5Y3/2)

Compacted older marsh mat

Abundant fibrous roots $>75 \%, 2 \mathrm{~cm}$ long

* sharp contact slightly deformed

$135-230 \mathrm{~cm}$

Dark Green Gray Mud (5G 4/1)

$50 \%$ clay $50 \%$ sand somewhat stiff

Clay clast at $170 \mathrm{~cm}$, tan in color.

Rare root traces

* sharp contact deformed

230-389cm Dark Green Gray Mud (5G 4/1)

Deformed parallel laminations may have been alternating mud with very fine grained sand.

More massive and hydrous in appearance

Very fine-grained sand $290-310 \mathrm{~cm}$

Clay clast $\sim 5 \mathrm{~cm}$ in length at $310 \mathrm{~cm}$

Parallel laminations of alternating silt with sand

from $310-389 \mathrm{~cm}$.

Tan mud layer $1.5 \mathrm{~cm}$ thick at $375 \mathrm{~cm}$

No organics 


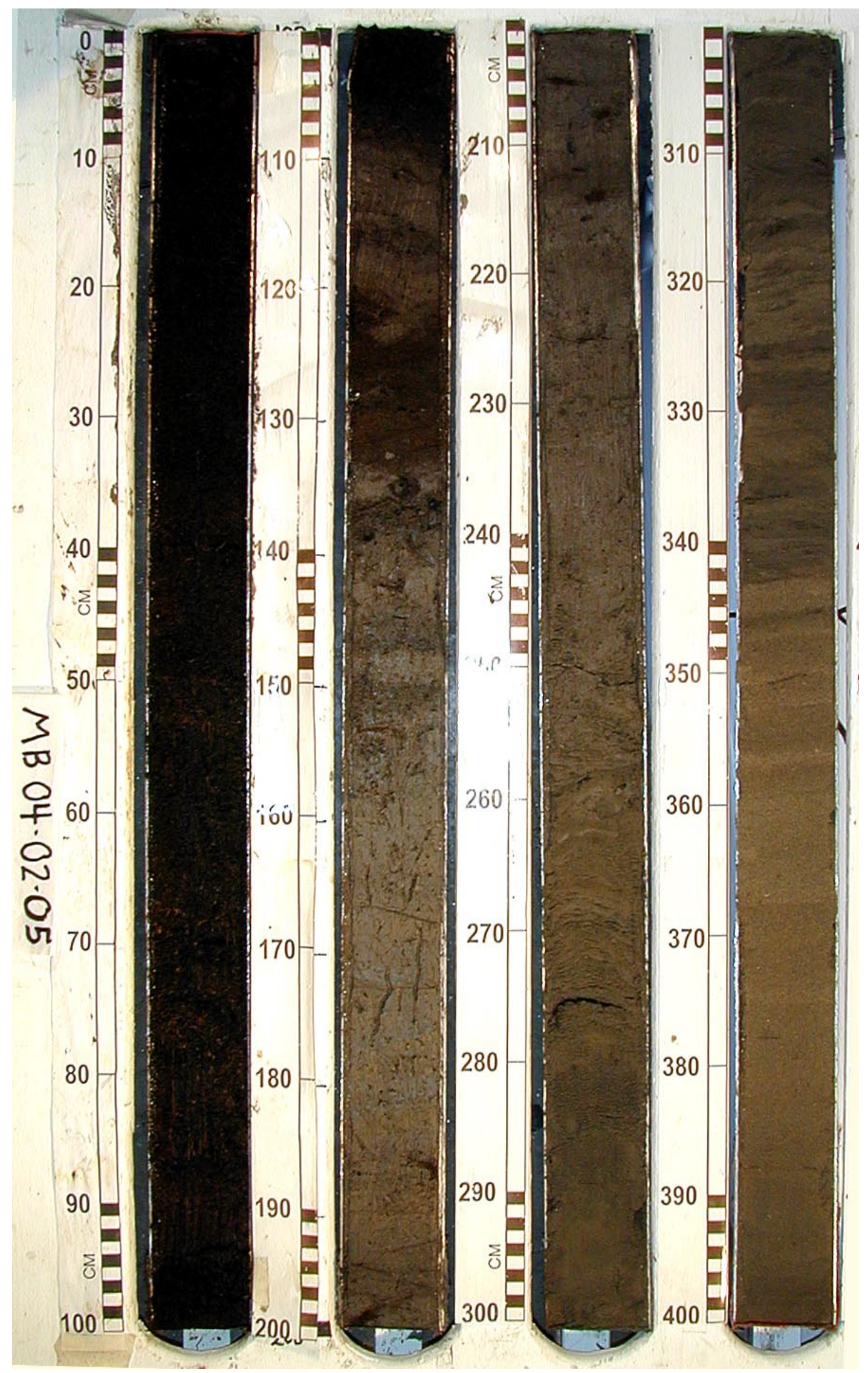


Core MB 04-02-05

Location: Madison Bay, Terrebonne Parish, LA

Latitude N29²1'29.52”'

Water depth $1.3 \mathrm{~m}$

Longitude W90³4'45.21”

Date obtained 04/30/02

Length recovered $4 \mathrm{~m}$

Date described 06/03/02

$0-105 \mathrm{~cm}$

Black Organic Peat

Black marsh mat, fibrous roots

$>90 \%$ organic

Some larger roots $\sim 5 \mathrm{~cm}$ in length from $60-80 \mathrm{~cm}$

* sharp contact

$105-120 \mathrm{~cm}$

Dark Olive Gray Mud

$(5 Y 3 / 2)$

$\sim 50-60 \%$ organics

Massive appearing

$120-130 \mathrm{~cm} \quad$ Olive Gray Muddy Peat (5Y 3/2)

Organic rich layer $>80 \%$

130-250cm Light Olive Gray Mud (5Y 5/2)

$\sim 50 \%$ clay and $50 \%$ silts

$\sim 20 \%$ roots/organics

Root traces well preserved

Organics decreasing down core

* gradational contact

250-342cm Light Olive Gray Silt and Sand (5Y 5/2)

Some clay in parallel laminae $\sim 0.5 \mathrm{~cm}$ thick

$\sim 40 \%$ sand $40 \%$ silt and $20 \%$ clay

* sharp contact

$342-400 \mathrm{~cm}$ Light Olive Silty Sand (5Y 5/2)

Massive appearing

No shells or organics 


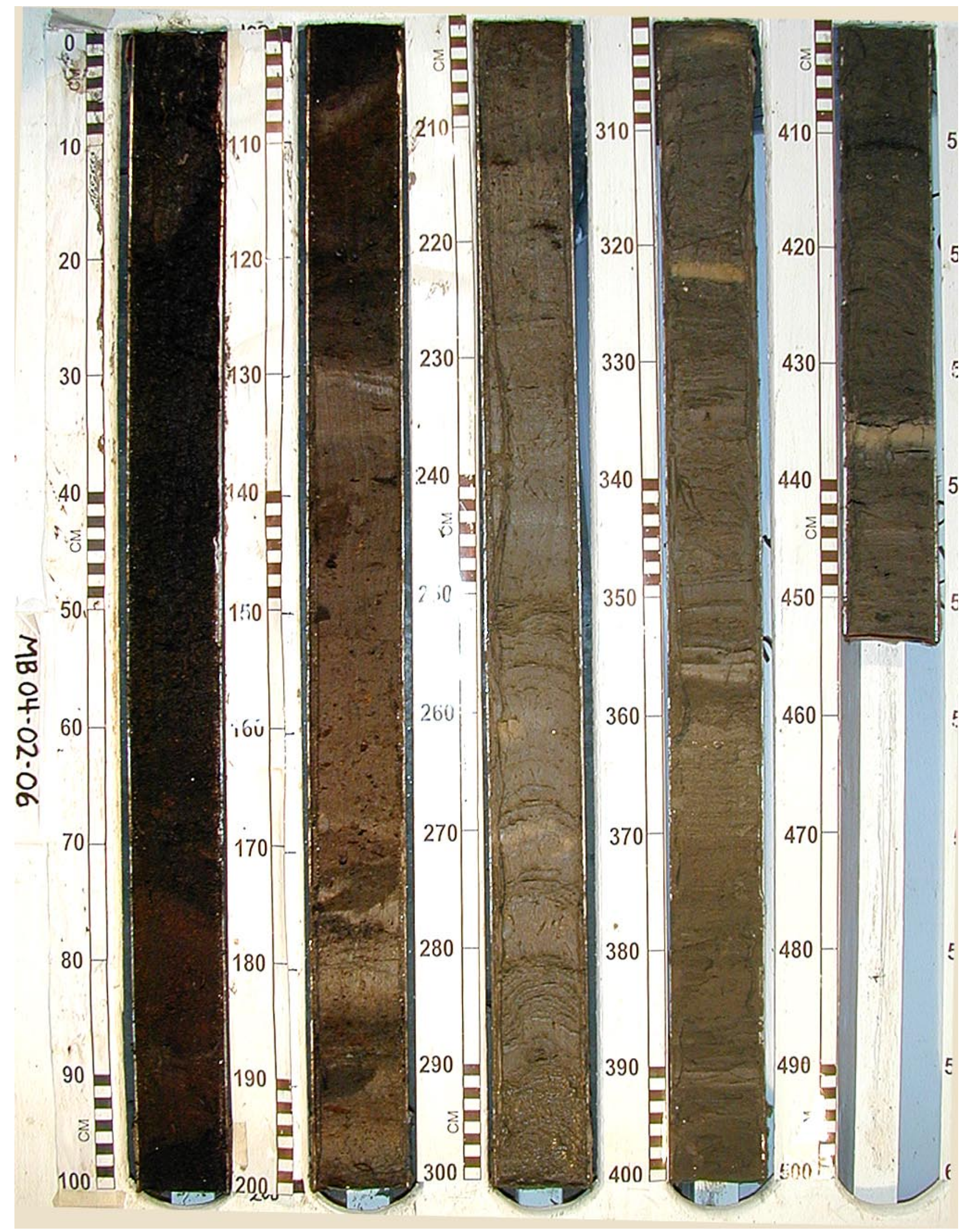


Core MB 04-02-06

Location: Madison Bay, Terrebonne Parish, LA

Latitude N2921'54.03"'

Water depth $1.01 \mathrm{~m}$

Longitude W90 34'56.59"

Date obtained 04/30/02

Length recovered $4.51 \mathrm{~m}$

Date described 06/03/02

$0-129 \mathrm{~cm}$

Black Organic Peat

Black marsh mat with abundant fibrous roots

Large roots in top $12 \mathrm{~cm}, \sim 5 \mathrm{~cm}$ in length

Color change $73-96 \mathrm{~cm}$ to dark olive gray $(5 \mathrm{Y} 4 / 2)$

Organic $>85 \%$ (marsh)

$97-106 \mathrm{~cm}$ color black again

$106-108 \mathrm{~cm}$ slightly deformed olive gray mud band $\sim 50 \%$ organics 108-129 black marsh again

* sharp contact

129-240cm Olive Gray Mud (5Y 3/2)

Massive appearing

$\sim 70 \%$ clay $\sim 30 \%$ silt $\sim 40 \%$ organics

Mostly roots or wood fragments near $187 \mathrm{~cm}$

Gradual color change down core to light olive gray (5Y 5/2)

Organics also decrease down core

* gradational contact

240-357cm Light Olive Gray Silty Sand (5Y 5/2)

$\sim 60 \%$ fine sand $\sim 40 \%$ silt

Possibly parallel laminated

Some finer grained layers at $301 \mathrm{~cm}$

$321 \mathrm{~cm}$ yellowish tan and $1 \mathrm{~cm}$ thick

Shell fragments at $323 \mathrm{~cm}$

* sharp contact

357-370cm Light Olive Gray Sand (5Y 5/2)

Mostly massive fine-grained sand, some silt

* gradational contact

$370-451 \mathrm{~cm} \quad$ Medium Olive Gray Sand

Sand is fine grained, some silt $\sim 25 \%$

Mica layer at $410 \mathrm{~cm}$

Shell fragments at $415 \mathrm{~cm}$

Yellowish tan mud layer $2 \mathrm{~cm}$ thick at $435 \mathrm{~cm}$ 


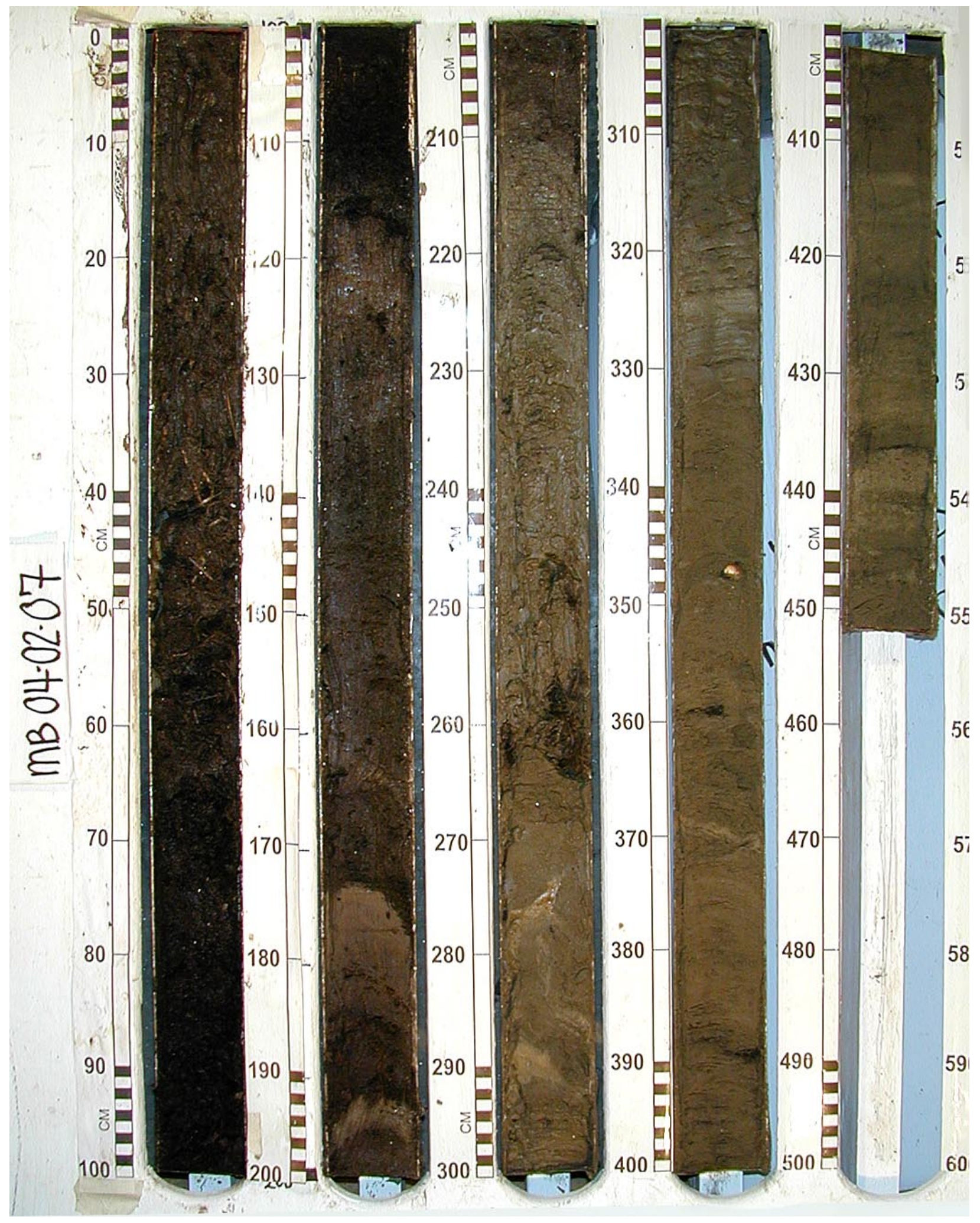


Location: Madison Bay, Terrebonne Parish, LA

Latitude N29²0'19.32'"

Longitude W90³6'04.31”'

Water depth $0.12 \mathrm{~m}$

Length recovered $4.50 \mathrm{~m}$

Date obtained 05/01/02

Date described 05/21/02

$0-20 \mathrm{~cm}$

Olive Gray Mud (5Y 3/2)

$30-40 \%$ fibrous roots

* gradational contact

$20-55 \mathrm{~cm} \quad$ Olive Gray Mud (5Y 3/2)

$60-70 \%$ large roots $\sim 5-6 \mathrm{~mm}$ circumference $\sim 10 \mathrm{~cm}$ long

Mostly clay

* gradational contact

$55-115 \mathrm{~cm}$

Black Organic Peat

Black marsh mat

$80-90 \%$ fibrous roots, organic rich mud

* gradational contact

115-208cm Olive Gray Organic Rich Mud (5Y 3/2)

$\sim 60-70 \%$ fibrous roots

Deformed clay beds at $176-184 \mathrm{~cm}$ and $195-197 \mathrm{~cm}$

Clay is light olive gray (5Y 5/2)

* sharp contact

208-299cm Light Olive Gray Silty Sand (5Y 5/2)

(60\% sand $40 \%$ silt)

Massive appearing

Possible faint parallel lamination

Large root mass at $260 \mathrm{~cm}$

* gradational contact

$299-312 \mathrm{~cm}$

Light Olive Gray Silty Sand

No organic roots

$60 \%$ sand $40 \%$ silt

312-412cm Light Olive Gray Silty Sand Massive appearing

Freshwater shell at $350 \mathrm{~cm}$

Organic lens at $362 \mathrm{~cm}$

* sharp contact

$412-450 \mathrm{~cm}$

Light Olive Gray Silty Sand Faint parallel laminations 


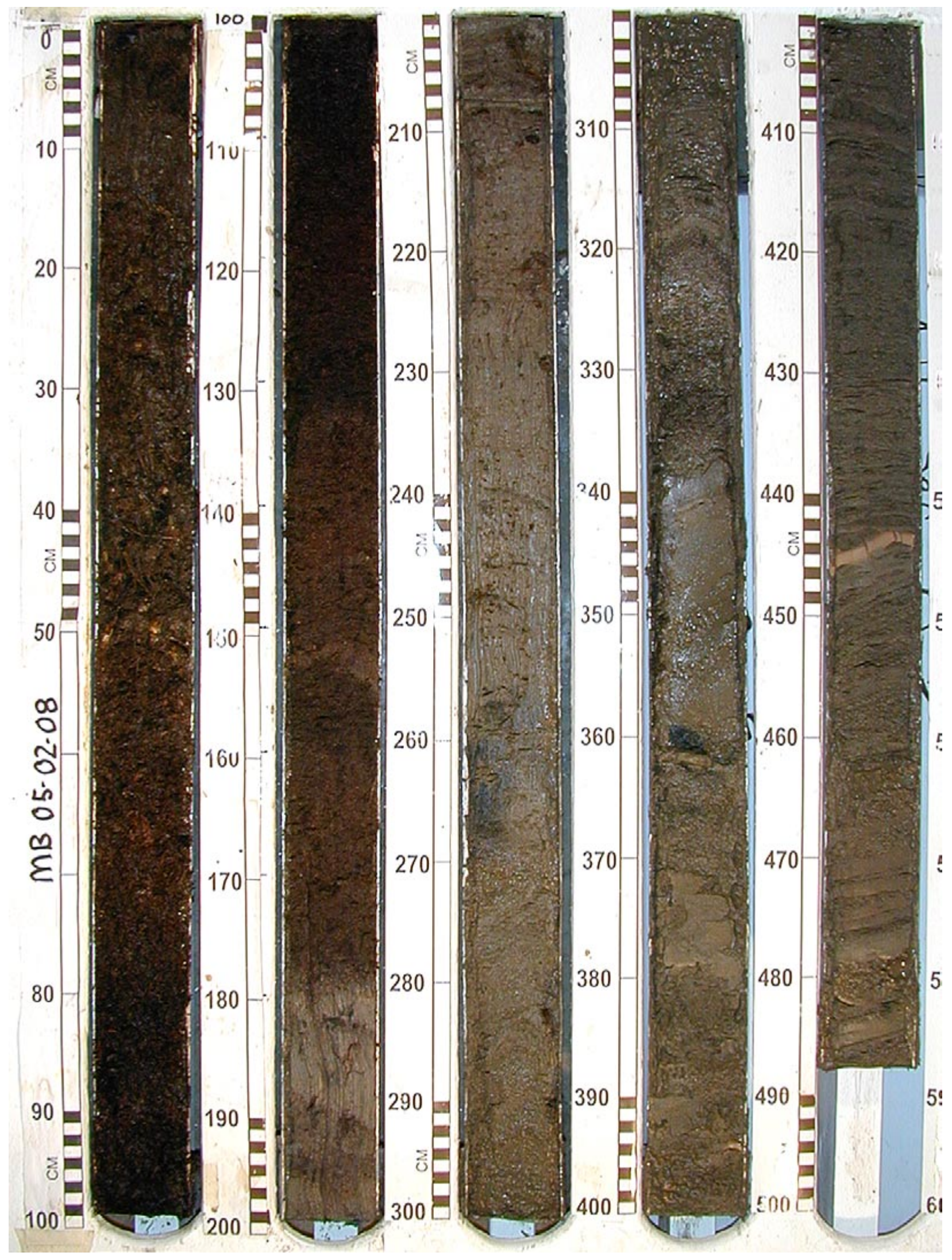


Core MB 05-02-08

Location: Madison Bay, Terrebonne Parish, LA

Latitude N29²0'08.83"

Water depth $0.21 \mathrm{~m}$

Longitude W90³4'51.09'

Date obtained 05/01/02

Length recovered $4.87 \mathrm{~m}$

Date described 05/30/02

$0-180 \mathrm{~cm}$

Olive Gray Peat (5Y 3/2)

Marsh Mat $>90 \%$ organics

$\sim 60 \%$ roots from $0-16 \mathrm{~cm}$

Large roots and fibrous roots of olive gray color $0-75 \mathrm{~cm}$

$75-180 \mathrm{~cm}$ black fibrous root mass $>90 \%$ organic

* sharp contact

180-266cm Medium Olive Gray Mud

$\sim 50 \%$ clay and $\sim 50 \%$ silt

$\sim 30-40 \%$ rooting, mostly root fragments

Black organic rich mud $262-264 \mathrm{~cm}$

* sharp contact

266-400cm Light Olive Gray Sandy Mud (5Y 5/2)

$\sim 60 \%$ mud $\sim 40 \%$ very fine sand coarsening down core

Organic rich layer at $327-330 \mathrm{~cm}$

clay clast $\sim 3 \mathrm{~cm}$ wide at $361 \mathrm{~cm}$

* gradational contact

400-487cm Light Olive Gray Mud and Sand (5Y 5/2)

Parallel lamination of mud and very fine sand

Yellowish gray lamination $(5 Y$ Y $7 / 2) \sim 1.5 \mathrm{~cm}$ thick at $444 \mathrm{~cm}$

Slight deformation during coring 


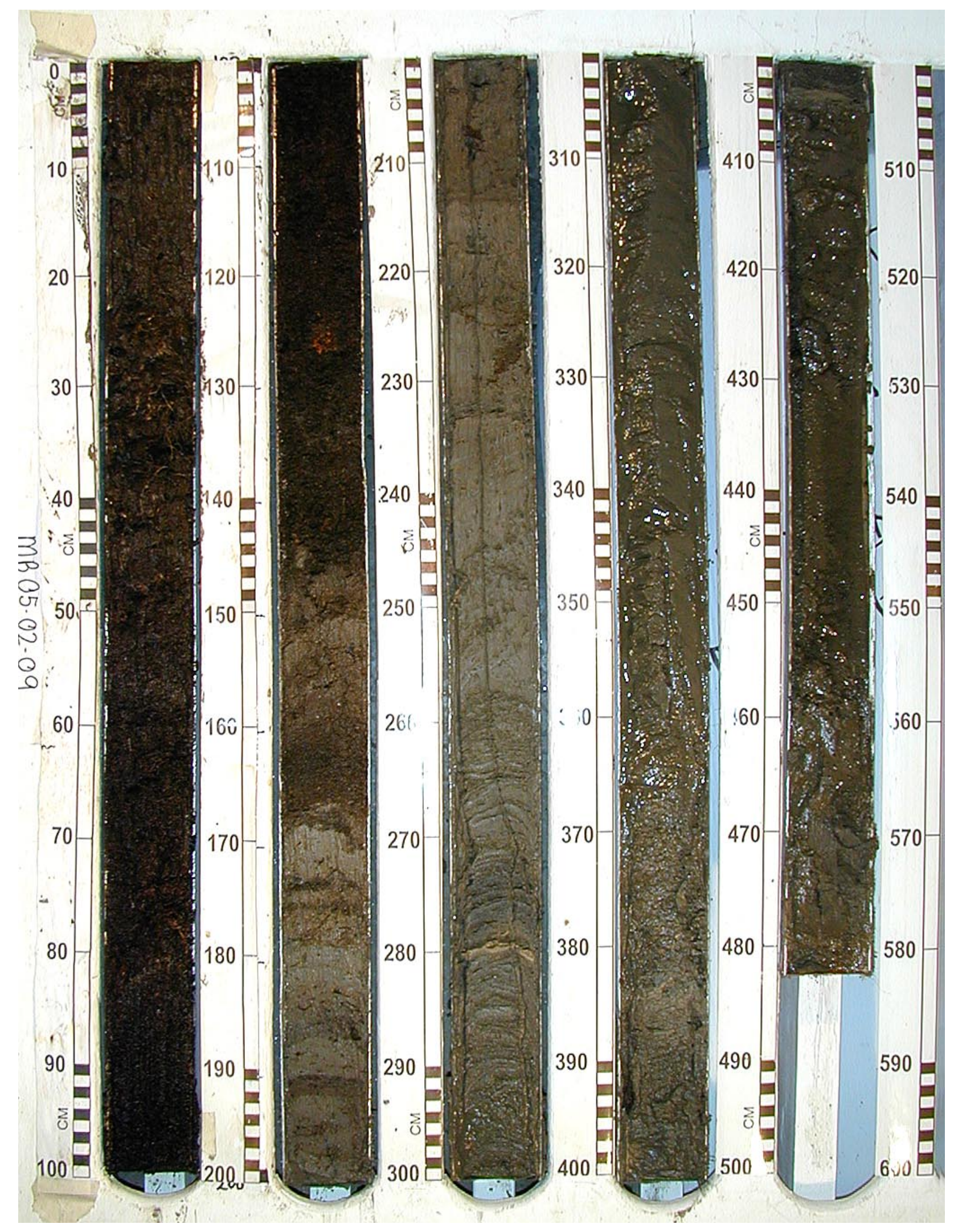


Core MB 05-02-09

Location: Madison Bay, Terrebonne Parish, LA

Latitude N29 $20^{\prime} 54.55^{\prime \prime}$

Water depth $0.27 \mathrm{~m}$

Longitude W90³4'29.06'

Date obtained 05/01/02

ength recovered $4.79 \mathrm{~m}$

Date described 06/05/02

$0-27 \mathrm{~cm}$

Olive Gray Mud (5Y 3/2)

$\sim 60 \%$ organic roots $\sim 3-4 \mathrm{~cm}$ long

* gradational contact

$27-146 \mathrm{~cm} \quad$ Black Peat

Black fibrous marsh mat $>90 \%$ organic matter

Root mass $30-40 \mathrm{~cm}$

Large fibrous roots $\sim 7 \mathrm{~cm}$

Seeds at $125 \mathrm{~cm}$

* sharp contact

146-160cm Olive Gray Mud (5Y 3/2)

Mud with $\sim 60 \%$ fibrous roots

* gradational contact

160-168cm Medium Olive Gray Peat

$>80 \%$ organic, fibrous roots

$168-259 \mathrm{~cm}$ Light Olive Gray Mud (5Y 5/2)

$\sim 60 \%$ clay $40 \%$ silt

massive appearing

$\sim 20-30 \%$ roots/organics

organics decreasing to 0 at basal contact

* sharp contact

259-300 cm Light Olive Gray Mud and Sand

Alternating parallel laminations

Sand is fine-grained

Yellowish tan bed at $280 \mathrm{~cm} 1 \mathrm{~cm}$ thick

* gradational contact

300-479cm Light Olive Gray Silty Sand

Massive appearing

Small clay $\%$, possibly mica fragments through section 


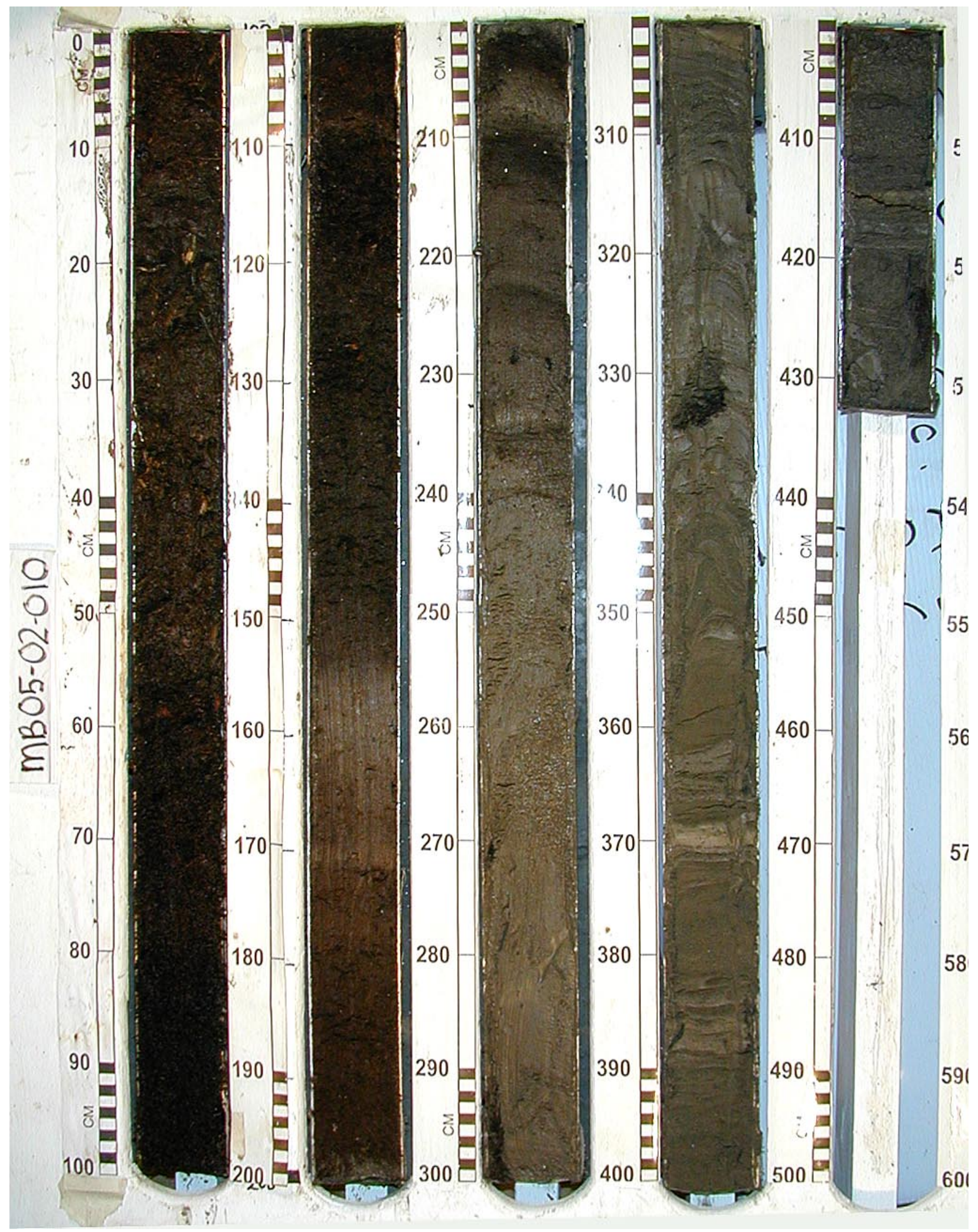


Core MB 05-02-10

Location: Madison Bay, Terrebonne Parish, LA

Latitude N29 $21^{\prime} 56.22^{\prime \prime}$

Water depth $0.18 \mathrm{~m}$

Longitude W90³4'56.56”

Date obtained 05/01/02

Length recovered $4.32 \mathrm{~m}$

Date described 06/04/02

\author{
0-48cm Olive Gray Peat (5Y 3/2) \\ $>85 \%$ large roots/root mat \\ Some roots $>4 \mathrm{~cm}$ long and $>2 \mathrm{~cm}$ wide \\ * gradational contact \\ $48-153 \mathrm{~cm} \quad$ Black Peat \\ Black marsh $>90 \%$ organic \\ Fibrous root material \\ * sharp contact \\ $153-173 \mathrm{~cm}$ Light Olive Gray Mud (5Y 5/2) \\ $\sim 60 \%$ clay $40 \%$ silt and $40 \%$ organics \\ massive appearing \\ * sharp contact \\ $173-195 \mathrm{~cm} \quad$ Black Peat \\ Organic-rich $>75 \%$ fibrous roots \\ * gradational contact \\ $195-240 \mathrm{~cm} \quad$ Olive Gray Mud \\ Organics decrease to $\sim 40 \%$ then disappear $\sim 240 \mathrm{~cm}$ \\ Dark gray mud band at $203-205 \mathrm{~cm}$ \\ * gradational contact \\ 240-337cm Light Olive Gray Mud \\ $\sim 50 \%$ clay $\sim 50 \%$ silt \\ Massive appearing \\ Hydrous large organic cluster at $336 \mathrm{~cm}$, possibly roots \\ $3 \mathrm{~cm}$ thick and $5 \mathrm{~cm}$ wide \\ * sharp contact \\ 337-432cm Light Olive Gray Silty Sand \\ Parallel lamination \\ Some massive appearing \\ Thicker beds of fine sand \\ Shell at $337 \mathrm{~cm}$
}


